ELIMINATING VIRAL HEPATITIS

\title{
Management of acute HCV infection in the era of direct-acting antiviral therapy
}

\author{
Marianne Martinello*, Behzad Hajarizadeh (1), Jason Grebely (), Gregory J. Dore \\ and Gail V. Matthews
}

Abstract | The management of acute HCV infection has not been standardized following the availability of direct-acting antiviral agents (DAAs) for chronic HCV infection, and substantial uncertainty exists regarding the optimal treatment regimen and duration. Despite the lack of direct evidence, the 2016 American Association for the Study of Liver Diseases (AASLD)Infectious Diseases Society of America (IDSA) guidelines supported "the same regimens for acute $\mathrm{HCV}$ as recommended for chronic HCV infection ... owing to high efficacy and safety", whereas the 2016 European Association for the Study of the Liver (EASL) guidelines recommended sofosbuvir-ledipasvir, sofosbuvir-velpatasvir or sofosbuvir plus daclatasvir for 8 weeks in acute $\mathrm{HCV}$ infection, with a longer duration of 12 weeks recommended for those infected with HIV and/or baseline HCV RNA levels $>1,000,000 \mathrm{IU} / \mathrm{ml}$. This Review outlines the epidemiology, natural history and diagnosis of acute $\mathrm{HCV}$ infection and provides contemporary information on DAAs for acute and recent HCV infection. The Review also discusses the 2016 AASLD-IDSA and EASL recommendations for acute $\mathrm{HCV}$ infection management in light of available evidence and highlights key differences in study populations and design that influence interpretation. We focus on populations at high risk of $\mathrm{HCV}$ transmission and acquisition, including people who inject drugs and HIV-positive men who have sex with men, and highlight the potential effects of diagnosis and treatment of acute HCV infection in contributing to HCV elimination.

Globally, an estimated 71 million people are living with chronic HCV infection, with $\sim 2$ million new infections occurring annually ${ }^{1,2}$. Key at-risk populations for HCV acquisition include people who inject drugs (PWID) and HIV-positive men who have sex with men $(\mathrm{MSM})^{3,4}$. Unsafe health-care practices (including unsterile health-care injection) account for a large proportion of new HCV infections in low-income and middle-income countries ${ }^{1,5}$.

One of the goals of the United Nations 2030 Agenda for Sustainable Development is the elimination of viral hepatitis as a public health threat, with targets including a $65 \%$ reduction in $\mathrm{HCV}$-related mortality and an $80 \%$ reduction in $\mathrm{HCV}$ incidence ${ }^{6,7}$. To realize these elimination targets, strategies to improve HCV diagnosis, treatment and prevention will be required ${ }^{8}$. Mathematical modelling suggests that substantial reductions in HCV incidence and prevalence can be achieved by scale-up of targeted HCV treatment among those at highest risk of ongoing transmission, including PWID and HIV-positive $\mathrm{MSM}^{9-12}$.
The development of direct-acting antiviral agents (DAAs; for example, grazoprevir-elbasvir ${ }^{13}$, sofosbuvirledipasvir ${ }^{14}$ and sofosbuvir-velpatasvir ${ }^{15}$ ) has revolutionized hepatitis $\mathrm{C}$ management and has provided the therapeutic tools required to strive for elimination ${ }^{16,17}$. With interferon-free DAAs established as the standard of care for chronic HCV infection, the optimal management of acute (duration of infection $<6$ months) and recent (duration of infection $<12$ months) $\mathrm{HCV}$ infection is uncertain. Much of the evidence regarding timing of treatment initiation, regimen choice and duration of therapy in recent HCV infection is based on small observational studies and randomized controlled trials of interferon-based therapy in selected populations. Administration of interferon-based therapy in recent $\mathrm{HCV}$ infection did offer a unique therapeutic advantage, with shorter treatment durations (4-12 weeks) and higher efficacy (SVR 72-87\%) ${ }^{18-22}$ in comparison with the same treatment in chronic HCV infection (duration 24-48 weeks, SVR $<60 \%)^{23,24}$. The efficacy and optimal duration of DAAs in recent $\mathrm{HCV}$ infection are being evaluated. 


\section{Key points}

- In 2015, an estimated 1.75 million new HCV infections occurred worldwide, with injection drug use and unsafe health-care practices being the predominant modes of transmission.

- Access to HCV care, education and treatment for people at high risk of onward transmission, including those with acute and recent $\mathrm{HCV}$ infection, should be a priority.

- Monitoring HCV RNA levels for between 4 and 12 weeks following diagnosis of acute infection provides an opportunity to assess for spontaneous clearance without compromising outcome.

- The role of (ultra-)short duration direct-acting antiviral agents in recent HCV infection is under investigation; pending the results of large trials, treatment is recommended with the same regimens as for chronic HCV infection.

- Screening of at-risk populations (at least annually) is recommended to improve diagnosis and treatment of acute HCV infection.

- Early detection and re-treatment of HCV reinfection, along with education and harm reduction, should be incorporated into the individual-level and population-level HCV response.
HCV infections in developed countries occurs among PWID ${ }^{3,32}$, with higher incidence in specific populations, including young adults (aged $<30$ years) ${ }^{33-38}$ and those who are incarcerated ${ }^{39-42}$. HCV acquisition risk is greatest among young adults who inject drugs in the first years of unsafe injection practices ${ }^{43,44}$.

Although stable or declining $\mathrm{HCV}$ incidence among PWID has been reported in some jurisdictions (including western Europe and Australia) ${ }^{45,46}$, sustained high or increasing incidence has been reported in other regions, including the developing world and the United States ${ }^{37,47-49}$. Data compiled by the US Centers for Disease Control and Prevention demonstrated that whereas HCV incidence remained fairly constant in all age groups between 2002 and 2014, an increase in incidence was noted between 2010 and 2014 in people aged 20-29 years (2010: 0.75 per 100,000; 2014: 2.20 per $100,000)$ and people aged 30-39 years (2010: 0.60 per 100,000; 2014: 1.66 per 100,000 $)^{48}$. This increase coincided with HCV (and HIV) infection outbreaks among PWID in non-urban communities and was frequently associated with misuse of prescription opiates before use of heroin ${ }^{37,47,50}$. Other demographic and clinical factors associated with HCV seroconversion include sharing injecting and drug preparation equipment, high injecting frequency, high number of injecting partners, type of drug injected, pooling money to purchase drugs, unstable housing and HIV co-infection ${ }^{43,45,51-54}$. Young female PWID are at greater risk of HCV acquisition than men $^{55,56}$, which is potentially related to high-risk injecting behaviours in the setting of coexisting sexual and injecting relationships $s^{55,57}$.

Access to health services and implementation of evidence-based harm reduction programmes are necessary to reduce the burden of HCV among PWID, with reduced HCV incidence seen among PWID receiving opioid substitution therapy (OST) ${ }^{36,45,53,58-62}$. Furthermore, the combination of OST and high-coverage needle and syringe programmes (ensuring adequate needles or syringes to cover all injecting episodes) can reduce $\mathrm{HCV}$ incidence by up to $80 \%^{52,59,63-67}$. $100,000)^{1,2}$. Although the HCV incidence seems to have decreased in the twenty-first century compared with that in the second half of the twentieth century (reviewed elsewhere ${ }^{25}$ ) in most jurisdictions, substantial regional variation exists, with continuing high $\mathrm{HCV}$ infection incidence in Europe $(61.8$ per 100,000$)$ and the eastern Mediterranean region (62.5 per 100,000) ${ }^{1}$. Country-specific data demonstrated that the annual $\mathrm{HCV}$ incidence peaked in the vast majority of countries between 1970 and 2005; the exception, with increasing HCV incidence, is Russia ${ }^{26,27}$. Although unsafe health-care procedures account for much of the HCV transmission in the eastern Mediterranean region ${ }^{28}$, injecting drug use predominates in Europe, particularly in eastern Europe $e^{1,29,30}$.

People who inject drugs. Of the estimated 1.75 million new HCV infections in 2015, 23\% were attributable to current injecting drug use $\mathrm{e}^{1}$ (with an estimated number of PWID aged 15-64 years in 2015 of 15.6 million and an anti-HCV antibody prevalence among PWID of $\left.53 \%{ }^{31}\right)$. The majority of new $(60 \%)$ and existing (80\%)
People with HIV infection. Increasing HCV infection incidence and prevalence have been reported in large cohorts of HIV-positive MSM over the past decade ${ }^{4,68-78}$, although the overall burden of disease remains markedly lower than that among PWID (with an estimated number of people living with HIV-HCV co-infection of 2.3 million (including 1.4 million PWID) and an anti-HCV antibody prevalence among people with HIV infection of 6.2\% (MSM 6.4\% and PWID 82.4\%) ${ }^{79}$ ). A meta-analysis examining $\mathrm{HCV}$ infection incidence in HIV-positive MSM who denied ever injecting drugs reported an increase in annual incidence from 0.4 per 100 person-years in 1991 to 1.3 per 100 person-years in $2012\left(\mathrm{REF}^{68}\right)$. However, differences in study design have resulted in high variability in incidence estimates between cohorts, with HCV infection incidence stabilizing or decreasing in some jurisdictions ${ }^{11,80}$. Given the changes to international guidelines promoting enhanced HCV screening among HIV-positive MSM, HCV testing, diagnosis and prevalence have increased in many 
Box 1 | Case definitions for acute HCV infection

\section{Anti-HCV antibody seroconversion}

The most accurate case definition of acute HCV infection is detection of HCV RNA levels in an individual with documented anti-HCV antibody seroconversion (with test conversion within 12 months) ${ }^{32,102-105}$.

\section{Acute clinical HCV infection}

An acute clinical illness with symptoms and signs consistent with acute viral hepatitis, including jaundice and/or elevated alanine aminotransferase (ALT) $>5-10$ times the upper limit of normal, with corresponding laboratory diagnostic evidence (positive anti-HCV antibody and/or detectable HCV RNA) ${ }^{32,102-105,130}$.

HCV RNA detected, anti-HCV antibody negative Detection of HCV RNA with a negative anti-HCV antibody result, followed by seroconversion, suggests very recent infection with exposure in the previous 6-8 weeks $^{32,103}$.

European countries, whereas incidence has plateaued or decreased in these same countries ${ }^{11,78,80}$.

The reported increase in HCV infection incidence in HIV-positive MSM has been associated with an increase in sexual risk behaviour and recreational drug use $^{68}$. Permucosal (sexual) HCV exposure (with blood as the medium) seems to facilitate HCV transmission, with risk factors for HCV acquisition including condomless traumatic anal intercourse, higher number of sexual partners, group sex, ulcerative sexually transmitted diseases and sexual acts that involve trauma and bleeding $68,69,73,74,81-83$. The increase in HCV infection incidence has occurred in parallel with certain behavioural trends in MSM communities, including use of social media sexual networking applications, 'serosorting' sexual behaviours (use of HIV serostatus in decision-making regarding sexual behaviour) and the phenomenon of 'chemsex' (illicit drug use, largely methamphetamine, before or during sex by both injecting and non-injecting routes of administration) ${ }^{83-88}$, highlighting that HIV-positive MSM and PWID are not mutually exclusive. HIV-positive MSM who inject drugs are at higher risk of HCV acquisition than HIV-positive MSM who do not inject drugs ${ }^{72}$. However, HIV-positive MSM who report injecting drug use could exhibit different drug use and sexual behaviours than non-MSM PWID populations traditionally reported in the HCV literature, and as such, different management and prevention strategies might need to be used.

Although similar sexual risk behaviours have been reported in HIV-positive and HIV-negative MSM, $\mathrm{HCV}$ infection incidence seems to be markedly lower in HIV-negative MSM $^{89-92}$. However, with increasing use of HIV pre-exposure prophylaxis (PrEP), there is the potential for a reduction in serosorting of sexual partners and increased sexual risk behaviour and transmission of HCV among HIV-positive and HIV-negative MSM populations ${ }^{83,88,93,94}$. Incident $\mathrm{HCV}$ infections have been observed in HIV-negative MSM receiving HIV $\operatorname{PrEP}^{92,94-96}$. Phylogenetic analysis of NS5B sequences obtained from HCV-positive HIV-negative MSM receiving PrEP in Amsterdam (the Netherlands) suggests that $\mathrm{HCV}$ transmission is occurring within discrete populations, with MSM-specific HCV clusters containing both HIV-positive and HIV-negative individuals ${ }^{88}$. Although current guidelines do not support routine HCV screening of HIV-negative MSM, the increasing use of HIV PrEP and overlapping behavioural networks support the monitoring of HCV incidence among high-risk MSM to guide policy.

Health-care-associated HCV transmission. Unsafe health-care procedures (including unsafe health-care injection, blood transfusion and other invasive medical procedures) continue to account for a substantial proportion of new HCV infections (15-20\% per year), largely in developing countries ${ }^{28,97,98}$. In 2010, an estimated 5\% of all health-care injections were given with unsterilized, reused equipment, resulting in an estimated 315,000 new HCV infections, most of which were in the eastern Mediterranean and southeast Asia ${ }^{98}$. Coupled with poor injection practices, excessive medication administration by injection contributes to transmission ${ }^{5,97}$. In these regions, training of health-care providers, structural changes to health-care models, effective screening and investment in HCV diagnostics, disposable materials (ideally with reuse-prevention devices) and effective sterilization procedures will be required to reduce health-care-associated HCV transmission ${ }^{5}$.

Following the broad implementation of universal infection control procedures, there have been marked declines in HCV incidence among haemodialysis populations in high-income countries ${ }^{99,100}$, a group previously at high risk of HCV acquisition. However, transmission outbreaks in dialysis units still occur ${ }^{101}$, screening is recommended in these patients ${ }^{102}$ and high HCV infection incidence and prevalence among dialysis-recipients in developing countries ${ }^{99}$ remain a concern.

\section{Diagnosis of acute HCV infection}

Difficulties in diagnosis. Acute HCV infection refers to the 6-month period following infection acquisition, though case definitions vary ${ }^{102-105}$ (BOX 1). Establishing the diagnosis of acute $\mathrm{HCV}$ infection can be challenging. Clinical features suggestive of acute $\mathrm{HCV}$ infection include marked elevation of alanine aminotransferase (ALT) levels ( $>5-10$ times the upper limit of normal) and an acute illness manifested by jaundice, fever, headache, malaise, anorexia, nausea, vomiting, diarrhoea or abdominal pain ${ }^{32,106}$. However, only $15-30 \%$ of those infected with HCV develop a symptomatic illness ${ }^{106}$, and ALT level elevation is nonspecific.

Anti-HCV antibody seroconversion provides the most accurate case definition, but the window between exposure and seroconversion is variable. Anti-HCV antibodies are usually detectable within 6-12 weeks of exposure ${ }^{107}$ but can take up to 12 months in immunocompromised individuals ${ }^{108-110}$ or might not occur at all $(<5 \% \text { of those exposed })^{110}$, necessitating assessment with HCV RNA levels as part of the initial evaluation in this population. Furthermore, individuals who have cleared previous HCV infection will remain indefinitely anti-HCV antibody positive ${ }^{32,111}$, and as such, HCV RNA level is required to diagnose reinfection. 
No definitive laboratory test exists to distinguish acute from chronic HCV infection. Certain features can be suggestive of acute infection, including low $\left(<10^{4}\right.$ international units $\left.(\mathrm{IU}) / \mathrm{ml}\right)$ or fluctuating $\left(>1 \log _{10} \mathrm{IU} / \mathrm{ml}\right)$ serum HCV RNA titre ${ }^{112,113}$. Although the use of HCV core antigen testing is supported for diagnosis of acute $\mathrm{HCV}$ infection ${ }^{105}$, test performance (largely sensitivity) and subsequent clinical utility are affected by the potential for low-level viraemia in acute infection, with the lower limit of HCV core antigen detection equivalent to 500-3,000 HCV RNA IU/ml depending on HCV genotype $e^{114,115}$.

Point-of-care tests for HCV infection, particularly for HCV RNA, have the potential to simplify diagnostic and screening algorithms, increase acute $\mathrm{HCV}$ infection diagnoses and facilitate early linkage to care and treatment. Point-of-care HCV testing can include oral fluid rapid diagnostic testing ${ }^{116-120}$, finger-stick whole blood rapid diagnostic testing ${ }^{117-122}$, on-site
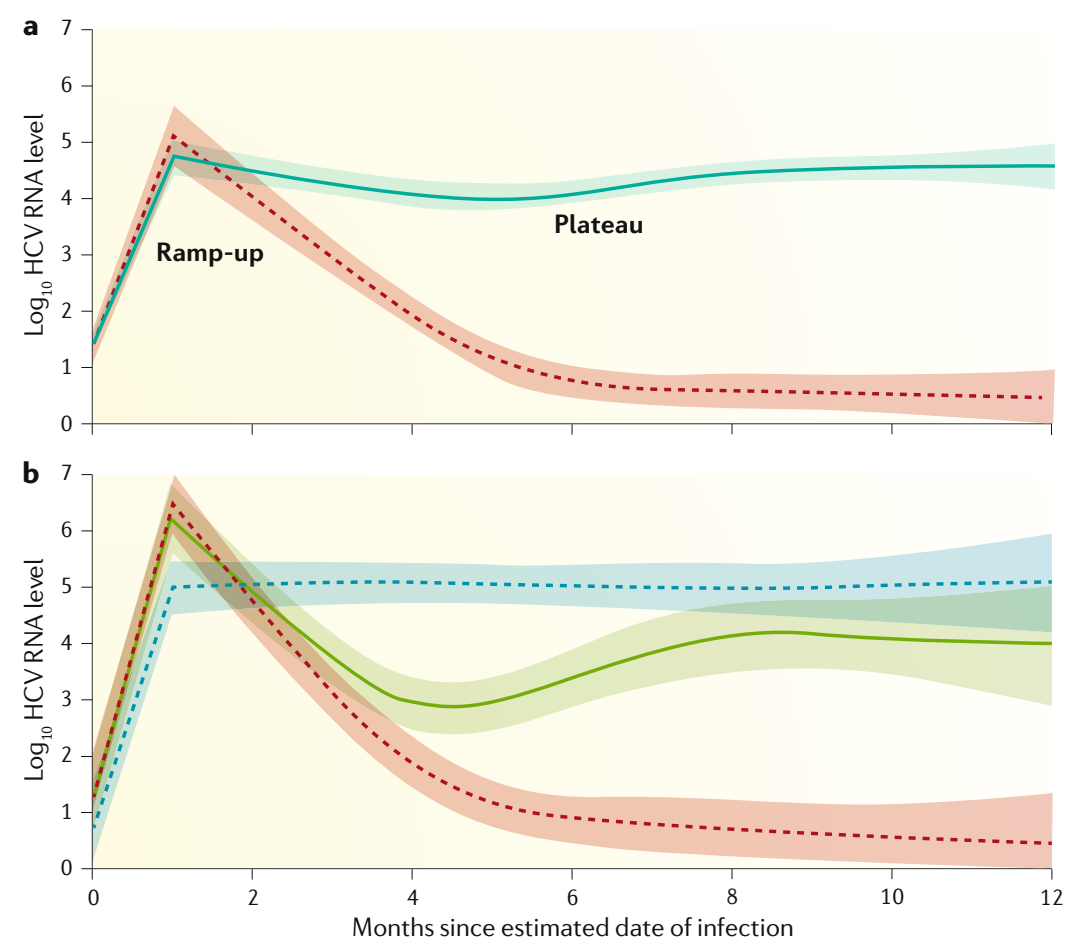

- - Spontaneous clearance - - Viral plateau with persistence - Persistent infection - Partial viral control with persistence

Fig. 1 | Viral kinetics in acute HCV infection. a | Acute HCV infection results in either spontaneous clearance (red) or viral persistence (blue green) and chronic HCV infection. Three phases have been described between exposure and seroconversion: the 'pre-ramp-up' phase (2-14 days) with intermittent low-level viraemia, potentially below the level of detection (not shown), the 'ramp-up' phase (8-10 days) with an exponential rise in HCV RNA and the 'plateau' phase (45-68 days) in which HCV RNA stabilizes. b | Divergence in HCV RNA dynamics in individuals who demonstrate spontaneous clearance and in those who have viral persistence occurs at approximately 3 months following infection. Among individuals with viral persistence, two HCV RNA patterns are noted - viral plateau with persistence (blue) and partial viral control with persistence (green). Among individuals with partial viral control and persistence, an initial marked decline in HCV RNA (potentially below the level of quantification) is followed by viral rebound, representing viral escape from innate responses or a failure of $\mathrm{HCV}$-specific adaptive responses. Adapted from REF. ${ }^{113}$, CC BY 4.0. venepuncture-based testing ${ }^{123,124}$ and finger-stick capillary whole blood testing ${ }^{125,126}$. Although most of these tests detect anti-HCV antibody, point-of-care $\mathrm{HCV}$ RNA assays that are available or in late-stage development include the Xpert HCV Viral Load (Cepheid) test, HCV ID Kit (Genedrive) and Truenat HCV (Molbio). Validation of these tests in the setting of recent $\mathrm{HCV}$ infection is ongoing.

Screening strategies in high-risk populations. Different screening strategies for HCV infection have been recommended and implemented depending on regional epidemiology $\mathrm{y}^{102,105,127,128}$. As documentation of seroconversion is often difficult, routine monitoring of at-risk populations is recommended to improve diagnosis of acute HCV infection. All PWID should be screened for HCV with anti-HCV antibody, and in the setting of ongoing injecting drug use, screening every 6-12 months should be performed to assess for incident infection ${ }^{102,105,129}$. Similarly, all newly diagnosed $\mathrm{HIV}$-positive individuals should be screened for $\mathrm{HCV}$ antibody ${ }^{102,130}$. HIV-positive MSM at risk of HCV acquisition should be reviewed every $6-12$ months with assessments for ALT levels and anti-HCV antibody ${ }^{130}$. After potential exposure (via injecting drug use and/or high-risk sexual behaviour) or diagnosis of a sexually transmitted infection in MSM, additional HCV screening with anti-HCV antibody should be considered and repeated 3 months later if negative ${ }^{130}$. HCV RNA assays should be performed if transaminases (particularly ALT) are elevated or if $\mathrm{HCV}$ reinfection is suspected ${ }^{131}$. If these recommendations are adhered to, both HCV primary infection and reinfection should be identified within the first year of acquisition. As such, a broader definition of recent $\mathrm{HCV}$ infection (duration of infection $<12$ months) has greater utility in guiding policy and management decisions.

\section{Management of recent HCV infection}

Natural history and spontaneous clearance. The natural history of recent HCV infection must be taken into consideration when determining the optimal management strategy. The complex interplay between host and virus in acute infection results in either viral persistence $(75-85 \%)$ or spontaneous clearance (15-25\%) $)^{132-136}$, with divergence in HCV RNA dynamics between the two groups occurring at approximately 3 months after infection ${ }^{113}$ (FIG. 1). In most cases, spontaneous clearance occurs in the first 6 months (67-86\%) or 12 months (83-95\%) following HCV acquisition ${ }^{137-140}$. Both host ${ }^{113,132,134,136,139,141-146}$ and viral ${ }^{113,136,147,148}$ factors have been associated with spontaneous clearance, although the evidence for and importance of host factors is most robust (BOX 2). Single-nucleotide polymorphisms in the IFNL3 and IFNL4 genes (formerly $I L 28 B$ ) have been identified that strongly predict both spontaneous clearance and clearance in response to interferon-based therapy ${ }^{136}$. Broad and multi-specific $\mathrm{CD}^{+}$and $\mathrm{CD}^{+} \mathrm{T}$ cell responses are associated with spontaneous clearance, whereas the failure of a sustained T cell response of sufficient magnitude is associated with viral persistence ${ }^{142,143}$. Unsurprisingly, immunocompromised hosts have a reduced chance of spontaneous 


\section{Box 2 | Factors associated with spontaneous clearance of HCV infection}

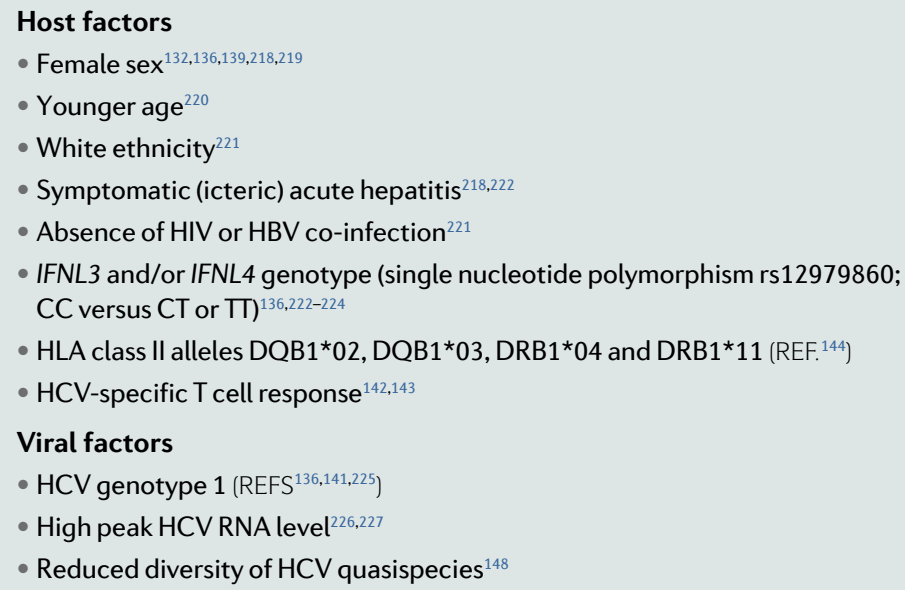

clearance $(\leq 20 \%)^{110,133,141,149-153}$. Despite extensive study of the innate and adaptive immune responses in acute and chronic HCV infection, the specific immunological characteristics during the acute phase of infection that predict clearance remain incompletely understood (reviewed elsewhere ${ }^{154,155}$ ).

Timing of HCV treatment initiation. The potential for spontaneous clearance needs to be weighed against early treatment initiation. Clinical trial data examining the utility of interferon-based therapy suggested that observation for 12 weeks following diagnosis of acute $\mathrm{HCV}$ infection provided an opportunity to assess for spontaneous clearance without compromising treatment efficacy, whereas a more prolonged delay ( $>12$ weeks) risked losing individuals to follow-up ${ }^{156,157}$. Additionally, monitoring HCV RNA kinetics in the first 4-12 weeks after diagnosis could assist in optimizing early treatment initiation ${ }^{12,137}$. For instance, among HIV-positive MSM, a decline in HCV RNA levels of $\geq 2 \log _{10} \mathrm{IU} / \mathrm{ml}$ at week 4 after diagnosis was associated with spontaneous clearance, whereas detectable HCV RNA at week 12 after diagnosis was associated with persistence ${ }^{130,158,159}$. Subsequent demonstration of the clinical utility of viral kinetic monitoring in the 4 weeks following diagnosis followed by early treatment (if spontaneous clearance is deemed unlikely) has influenced acute HCV treatment recommendations in this population ${ }^{130,159,160}$.

There is no role for pre-exposure or post-exposure prophylaxis in $\mathrm{HCV}$ infection ${ }^{102,105}$. The natural history of $\mathrm{HCV}$ infection, efficacy of DAAs and cost-effectiveness modelling do not support pre-emptive therapy ${ }^{161}$. Instead, appropriate testing and expedient treatment, if required, are recommended.

DAAs for acute and recent $H C V$ infection. The treatment paradigm for chronic $\mathrm{HCV}$ infection has evolved rapidly, with dual-class and triple-class DAA regimens for 8-12 weeks achieving very high SVR (>95\%) in treatment-naive individuals without cirrhosis ${ }^{16,17}$. Although this DAA approach has markedly reduced the relevance of enhanced interferon-based treatment outcomes in acute $\mathrm{HCV}$ infection, the potential for shortened duration therapy in acute and recent HCV infection underpins current treatment recommendations and research questions. Compared with chronic HCV infection (treatment duration 24-48 weeks, SVR at 24 weeks (SVR24) $<60 \%)^{23,24}$, clinical trials of shortened duration (4-12 weeks) PEG-IFN with and without ribavirin demonstrated superior efficacy in acute and recent HCV infection (SVR24 72-87\%) ) $^{18-22}$, with similar efficacy in populations with acute $(<6 \text { months })^{19,20,157,162-166}$ and early chronic (6-24 months) infection ${ }^{22,166}$.

The optimal management of acute $\mathrm{HCV}$ infection in the era of DAAs is yet to be defined. The 2016 AASLDIDSA guidelines support "the same [direct-acting antiviral] regimens for acute $\mathrm{HCV}$ as recommended for chronic HCV infection ... owing to high efficacy and safety" (level of evidence: class IIa, level C), whereas the 2016 EASL guidelines recommend sofosbuvir plus a non-structural protein $5 \mathrm{~A}$ (NS5A) inhibitor (sofosbuvirledipasvir, sofosbuvir-velpatasvir or sofosbuvir plus daclatasvir) for 8 weeks in acute HCV infection (level of evidence: class IIb, level C), with a longer duration of 12 weeks recommended for those with HIV and/or baseline HCV RNA $>1,000,000\left(>6 \log _{10}\right)$ IU/ml (level of evidence: class IIb, level C). Current international recommendations for the treatment of acute $\mathrm{HCV}$ infection are controversial, are not supported by robust evidence and will evolve pending the results of current and future clinical trials. Several small clinical trials and cohort studies of shortened duration DAA therapy have been conducted (TABLE 1; Supplementary Table 1), and larger trials are underway (TABLE 2) to fill this evidence gap. Pilot studies of a single DAA, sofosbuvir, with ribavirin showed suboptimal efficacy in acute and recent HCV infection and are not recommended ${ }^{167,168}$.

Shortened duration dual-class and triple-class DAA regimens for 4, 6 and 8 weeks have demonstrated promising results (FIG. 2). In acute HCV genotype 1 mono-infection, very high SVR was demonstrated with 6 weeks of sofosbuvir-ledipasvir (26 of 26 patients; SVR at 12 weeks (SVR12) intention to treat (ITT) $100 \%)^{169}$. Notably, PWID were excluded, and the vast majority of study participants had symptomatic infection and low baseline HCV RNA levels (median $4.0 \log _{10} \mathrm{IU} / \mathrm{ml}$; $\left.\leq 3 \log _{10} \mathrm{IU} / \mathrm{ml}, 45 \%\right)$. Again, in a preliminary report in acute HCV genotype 1 mono-infection, high SVR was demonstrated with 4 weeks of sofosbuvir-ledipasvir (14 of 14 patients; SVR12 ITT 100\%) and 8 weeks of sofosbuvir plus simeprevir (13 of 15 patients; SVR12 ITT $87 \%)^{170}$. Viral suppression was rapid, with HCV RNA levels below the limit of detection in $93 \%$ at week 1 among participants who received either sofosbuvirledipasvir or sofosbuvir plus simeprevir. Current PWID were excluded. This study is yet to be formally published, and as such, without a fuller description of the study design, definitions and methodology, no firm conclusions can be drawn. Among HIV-positive MSM, lower SVR (20 of 26 patients; SVR12 ITT 77\%; per-protocol $87 \%$ ) was demonstrated with 6 weeks of sofosbuvirledipasvir for acute $\mathrm{HCV}$ genotypes $1 \mathrm{a}$ and $4\left(\mathrm{REF}^{171}\right)$. The mean baseline HCV RNA level was $5.4 \log _{10} \mathrm{IU} / \mathrm{ml}$. The majority of study participants were asymptomatic; two participants presented with jaundice, and both were 
Table 1 | Interferon-free direct-acting antiviral agent clinical trials in acute and recent HCV infection

\begin{tabular}{|c|c|c|c|c|c|c|c|c|c|}
\hline $\begin{array}{l}\text { Study setup (year; } \\
\text { country; design) }\end{array}$ & $\begin{array}{l}\text { Protocol- } \\
\text { defined } \\
\text { duration of } \\
\text { infection at } \\
\text { screening } \\
\text { (months) }\end{array}$ & $\begin{array}{l}\text { Duration of } \\
\text { infection } \\
\text { at baseline } \\
\text { (weeks), } \\
\text { median } \\
\text { (range) }\end{array}$ & $\begin{array}{l}\text { PWID } \\
\text { (\%) }\end{array}$ & $\begin{array}{l}\text { HIV } \\
(\%)\end{array}$ & $\begin{array}{l}\text { HCV } \\
\text { genotype }\end{array}$ & $\begin{array}{l}\text { Baseline } \\
\text { HCV RNA } \\
\text { level } \\
\text { ( } \log _{10} \text { IU/ml), } \\
\text { median } \\
\text { (range) }\end{array}$ & $\begin{array}{l}\text { Baseline HCV RNA } \\
>1,000,000 \mathrm{IU} / \mathrm{ml}, \\
n(\%)\end{array}$ & $\begin{array}{l}\text { Regimen, } \\
\text { duration } \\
\text { (weeks) }\end{array}$ & $\begin{array}{l}\text { SVR12 } \\
\text { (ITT) }\end{array}$ \\
\hline \multicolumn{10}{|l|}{ Clinical trials } \\
\hline $\begin{array}{l}2016\left(\text { REF. }^{167}\right) \text {; Australia } \\
\text { and New Zealand; } \\
\text { multicentre }\end{array}$ & $\leq 12$ & $37(12-55)$ & 84 & 74 & $\begin{array}{l}\text { 1a: } 68 \% \\
\text { 2b: } 5 \% \\
3: 26 \%\end{array}$ & $5.4(1.5-7.4)$ & $8(42)$ & $\begin{array}{l}\text { SOF }+ \text { RBV } \\
\text { (6) }\end{array}$ & $\begin{array}{l}32 \% \\
(6 / 19)\end{array}$ \\
\hline $\begin{array}{l}\left.2017 \text { (REF. }{ }^{168}\right) ; \text { USA; } \\
\text { multicentre }\end{array}$ & $\leq 6$ & $20^{\mathrm{a}}(13-25)$ & 24 & 100 & $\begin{array}{l}\text { 1a: } 65 \% \\
\text { 1b: } 12 \% \\
1: 12 \% \\
\text { 2b: } 6 \%\end{array}$ & $6.4(5.4-6.6)^{b}$ & $11(65)$ & $\begin{array}{l}\text { SOF }+ \text { RBV } \\
(12)\end{array}$ & $\begin{array}{l}59 \% \\
(10 / 17)\end{array}$ \\
\hline $\begin{array}{l}2016\left(\text { REF }^{170}{ }^{10} \text {; }\right. \\
\text { Germany; multicentre }\end{array}$ & $\leq 4$ & U & 0 & 0 & $\begin{array}{l}\text { - 1a: } 55 \% \\
\text { - 1b: } 45 \%\end{array}$ & $4.0(1.2-7.2)$ & $2(10)$ & $\begin{array}{l}\text { SOF-LDV } \\
\text { (6) }\end{array}$ & $\begin{array}{l}100 \% \\
(20 / 20)\end{array}$ \\
\hline $\begin{array}{l}2017 \text { (REF. }{ }^{175} \text { ); Germany } \\
\text { and UK; multicentre }\end{array}$ & $\leq 6$ & U & U & 100 & $\begin{array}{l}\text { - } 1 \mathrm{a}: 73 \% \\
\text { - } 4: 27 \%\end{array}$ & $5.4^{\mathrm{c}}(1.1-7.3)$ & $10(38)$ & $\begin{array}{l}\text { SOF-LDV } \\
\text { (6) }\end{array}$ & $\begin{array}{l}77 \% \\
(20 / 26)\end{array}$ \\
\hline $\begin{array}{l}2017\left(\text { REF. }^{172}\right) \text {; Australia, } \\
\text { England and } \\
\text { New Zealand; } \\
\text { multicentre }\end{array}$ & $\leq 12$ & $30(11-51)$ & 53 & 77 & $\begin{array}{l}\text { 1a: } 93 \% \\
\text { - } 1 \text { b: } 3 \% \\
\text { 1 or no } \\
\text { subtype: } 3 \%\end{array}$ & $5.7(2.7-7.3)$ & $13(43)$ & $\begin{array}{l}\operatorname{PrOD} \pm \mathrm{RBV} \\
\text { (8) }\end{array}$ & $\begin{array}{l}97 \% \\
(29 / 30)\end{array}$ \\
\hline $\begin{array}{l}2017\left(\text { REF. }^{171} \text { ) (abstract }\right. \\
\text { only); USA; multicentre }\end{array}$ & $\leq 6$ & U & 19 & 100 & $\begin{array}{l}\text { - } 1: 96 \% \\
\text { - } 4: 4 \%\end{array}$ & $6.2(4.5-6.6)^{b}$ & NA & $\begin{array}{l}\text { SOF-LDV } \\
\text { (8) }\end{array}$ & $\begin{array}{l}100 \% \\
(27 / 27)\end{array}$ \\
\hline \multicolumn{10}{|l|}{ Cohort studies } \\
\hline \multirow[t]{2}{*}{$\begin{array}{l}2015 \text { (REF. }{ }^{170} \text { ) (abstract } \\
\text { only); USA; multicentre }\end{array}$} & Not defined & U & 100 & 0 & $\begin{array}{l}\text { - 1a: } 50 \% \\
\text { - } 1 \text { b: } 50 \%\end{array}$ & $6.1^{\mathrm{d}}$ & U & $\begin{array}{l}\text { SOF-LDV } \\
\text { (4) }\end{array}$ & $\begin{array}{l}100 \% \\
(14 / 14)\end{array}$ \\
\hline & & U & 100 & 0 & $\begin{array}{l}\text { - 1a: } 47 \% \\
\text { - } 1 \text { b: } 53 \%\end{array}$ & $6.2^{\mathrm{d}}$ & U & $\begin{array}{l}\mathrm{SOF}+\mathrm{SIM} \\
(8)\end{array}$ & $\begin{array}{l}93 \% \\
(13 / 15)\end{array}$ \\
\hline $\begin{array}{l}2017\left(\text { REF. }^{231}\right) \text {; USA; } \\
\text { single centre }\end{array}$ & Not defined & $22^{e}(4-38)$ & 37 & 100 & $\begin{array}{l}\text { - } 1 \mathrm{a}: 83 \% \\
\text { - } 1 \mathrm{~b}: 17 \%\end{array}$ & $4.5(1.7-7.5)$ & $4(33)$ & $\begin{array}{l}\text { SOF + RBV } \\
(12)\end{array}$ & $\begin{array}{l}92 \% \\
(11 / 12)\end{array}$ \\
\hline
\end{tabular}

ITT, intention to treat; IU, international units; LDV, ledipasvir; MSM, men who have sex with men; NA, not available; PrOD, paritaprevir-ritonavir-ombitasvir + dasabuvir; PWID, people who inject drugs; RBV, ribavirin; SIM, simeprevir; SOF, sofosbuvir; SVR12, SVR at 12 weeks; U, unknown. ${ }^{\mathrm{a} T i m e}$ from first laboratory evidence of acute $\mathrm{HCV}$ infection until study entry. ${ }^{\mathrm{b}}$ Median (interquartile range). ${ }^{\mathrm{c}}$ Mean (range). ${ }^{\mathrm{d}}$ Mean HCV RNA level. ${ }^{\mathrm{e}}$ Time from diagnosis to treatment commencement.

receiving atazanavir. Of the six participants who did not achieve SVR12, three experienced post-treatment relapse, one was reinfected before post-treatment week 4, and two were lost to follow-up after achieving SVR4. The three participants with relapse had high baseline HCV RNA levels (>6.9 $\left.\log _{10} \mathrm{IU} / \mathrm{ml}\right)$. Among people with acute and recent HCV genotype 1, excellent efficacy has been reported with 8 weeks of paritaprevir-ritonavirombitasvir and dasabuvir ${ }^{172}$ (29 of 30 patients; SVR12 ITT 97\%; per-protocol 100\%) and in a preliminary report with 8 weeks of sofosbuvir-ledipasvir ${ }^{171}$ (27 of 27 patients; SVR12 ITT 100\%). Combined, these pilot studies offer exciting potential but are limited by small sample sizes, selected populations and, in some cases, lack of formal published results.

Marked differences in study design and cohort characteristics limit meaningful comparison and generalization with published guidelines (TABLE 2; Supplementary Table 1). Most of the study populations have been highly selected, often delineated by HIV serostatus. Unfortunately, current PWID have largely been excluded ${ }^{169,170,173}$, a population in which targeted screening and treatment of acute $\mathrm{HCV}$ infection could be most useful to prevent ongoing transmission. Additionally, different or unclear definitions of duration of infection make comparison and implementation uncertain. As the distinction between acute and early chronic infection is somewhat arbitrary, further research regarding treatment initiation within 1 year of infection would permit broad clinical application.

\section{Predictors of response to shortened duration DAA} therapy in acute $\mathrm{HCV}$ infection. Baseline $\mathrm{HCV}$ RNA level and early on-treatment viral kinetics seem to influence response to short duration DAA therapy (treatment duration $\leq 6$ weeks) ${ }^{174}$. A higher baseline HCV RNA level ( $\left.>6 \log _{10} \mathrm{IU} / \mathrm{ml}\right)$ seems to be associated with post-treatment relapse following short duration therapy in acute ${ }^{167,175}$ and chronic ${ }^{176} \mathrm{HCV}$ infection. In preliminary results from two acute $\mathrm{HCV}$ infection clinical trials examining an 8-week duration of sofosbuvir-ledipasvir ${ }^{171}$ and paritaprevir-ritonavir-ombitasvir and dasabuvir ${ }^{172}$, baseline HCV RNA level did not affect efficacy.

Given the potential for high, fluctuating HCV RNA levels in recent HCV infection ${ }^{113}$, an ultra-short duration therapeutic strategy might require stratification by baseline HCV RNA titres. There is precedent for this approach in chronic HCV infection, with post hoc analysis of the ION-3 trial forming the basis for prescribing guidelines regarding shortening the treatment duration of sofosbuvir-ledipasvir from 12 weeks to 8 weeks in treatment-naive individuals who have chronic 
Table 2 | Registered interferon-free direct-acting antiviral agent clinical trials in acute and recent HCV infection

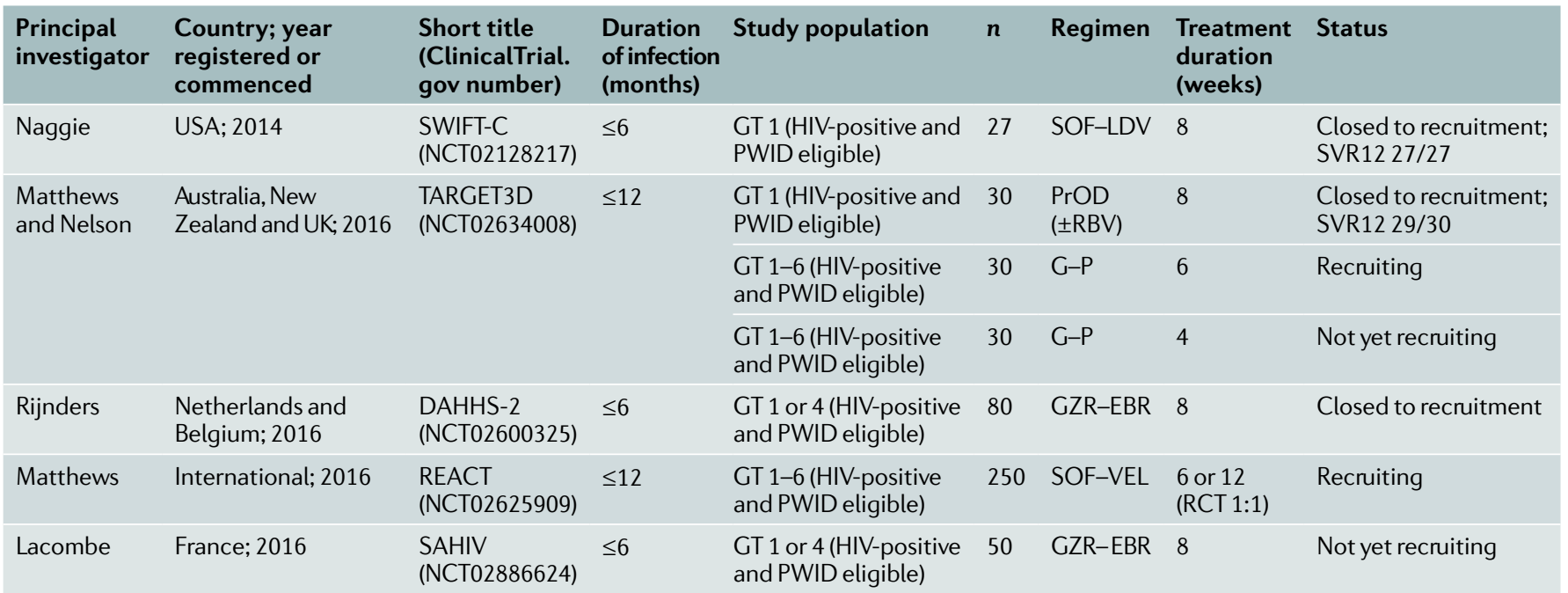

EBR, elbasvir; G-P, glecaprevir-pibrentasvir; GT, genotype; GZR, grazoprevir; LDV, ledipasvir; PrOD, paritaprevir-ritonavir-ombitasvir plus dasabuvir; PWID, people who inject drugs; RBV, ribavirin; RCT, randomized controlled trial; SOF, sofosbuvir; SVR12, SVR at 12 weeks; VEL, velpatasvir.

HCV genotype 1 infection and baseline HCV RNA levels $<6,000,000 \mathrm{IU} / \mathrm{ml}$ but do not have cirrhosis ${ }^{14,177,178}$. Among treatment-naive individuals in China with chronic HCV genotype $1 \mathrm{~b}$ infection and without cirrhosis $(n=18)$, a pilot study evaluated ultra-short duration response-guided triple-class DAA therapy ${ }^{179}$. Very high SVR (100\%) was seen among those who received 3 weeks of DAAs after achieving an ultra-rapid viral response (defined as HCV RNA titre $<500 \mathrm{IU} / \mathrm{ml}$ after $48 \mathrm{~h}$ ). Participants with an ultra-rapid viral response had a significantly lower mean baseline HCV RNA level than those without an ultra-rapid viral response (HCV RNA $6.0 \log _{10} \mathrm{IU} / \mathrm{ml}$ (s.d. 0.8) versus $7.0 \log _{10} \mathrm{IU} / \mathrm{ml}$ (s.d. 0.3); $P<0.001$ ), suggesting that baseline HCV RNA levels can assist in predicting which individuals might respond favourably to short duration therapy, although the findings need confirmation in other populations (such as in different ethnicities or in patients infected with different genotypes). Although the 2016 EASL guidelines support stratification of treatment duration by HIV serostatus and baseline HCV RNA levels ${ }^{105}$, the evidence for this recommendation is very limited.

Future research directions. The role, efficacy and cost-effectiveness of interferon-free DAA therapy in the management of recent $\mathrm{HCV}$ infection require further evaluation. It is uncertain whether the paradigm of shortened treatment duration in recent, as compared with chronic, HCV infection will hold true with interferon-free therapy. Although the data from small studies support this concept (TABLE 1), the results of larger (randomized) clinical trials are awaited to confirm these findings (TABLE 2). To robustly evaluate the efficacy of ultra-short duration DAA therapy, optimal regimen choice will be critical. Mathematical modelling suggests that rapid on-treatment second-phase viral decline, as seen after administration of $\mathrm{HCV}$ non-structural protein 3 (NS3) and/or non-structural protein $4 \mathrm{~A}$ (NS4A) protease inhibitors and NS5A inhibitors, permits shorter (potentially by weeks) treatment durations ${ }^{180,181}$. Additional modelling suggests that analysis of early on-treatment viral kinetics reduces DAA treatment duration, with individualized (response-guided) therapy associated with a projected average cost saving of $16-20 \%$ per 100 patients with chronic HCV infection treated ${ }^{174}$. However, treatment individualization increases complexity and limits utility. Cost-effectiveness analysis supports the immediate treatment of acute HCV infection with short duration DAAs (4-6 weeks) as compared with treatment deferral until chronic infection (treatment duration 8-12 weeks), as there are cost savings associated with shorter duration and reduced transmission ${ }^{182}$.

The effect of clinical, virological and immunological factors on efficacy, as measured by factors such as HIV infection, baseline HCV RNA levels, clinical presentation and duration of infection, remains to be adequately determined. Although administration of interferon in acute HCV infection seemed to have a unique role in improving response to therapy owing to differences in expression of interferon-stimulated genes $^{183}$, the effect of host genetics and immune response on treatment outcome with DAAs in recent $\mathrm{HCV}$ infection is unknown.

Studies to date have been largely restricted to acute HCV genotype 1 infection ${ }^{169,175}$. A pan-genotypic strategy would be ideal for clinical implementation and might permit a simplified management strategy in which assessment of HCV genotype is no longer required and a single short duration DAA regimen would be suitable for most people with acute and recent HCV infection. The FDA approval of glecaprevir-pibrentasvir in August 2017 (REF. ${ }^{184}$ ), an 8-week pan-genotypic regimen for people with chronic HCV infection without cirrhosis (fibrosis stage $0-3$ ), suggests that such an approach is possible for the vast majority of people infected with $\mathrm{HCV}$ regardless of duration of infection. Large studies of 


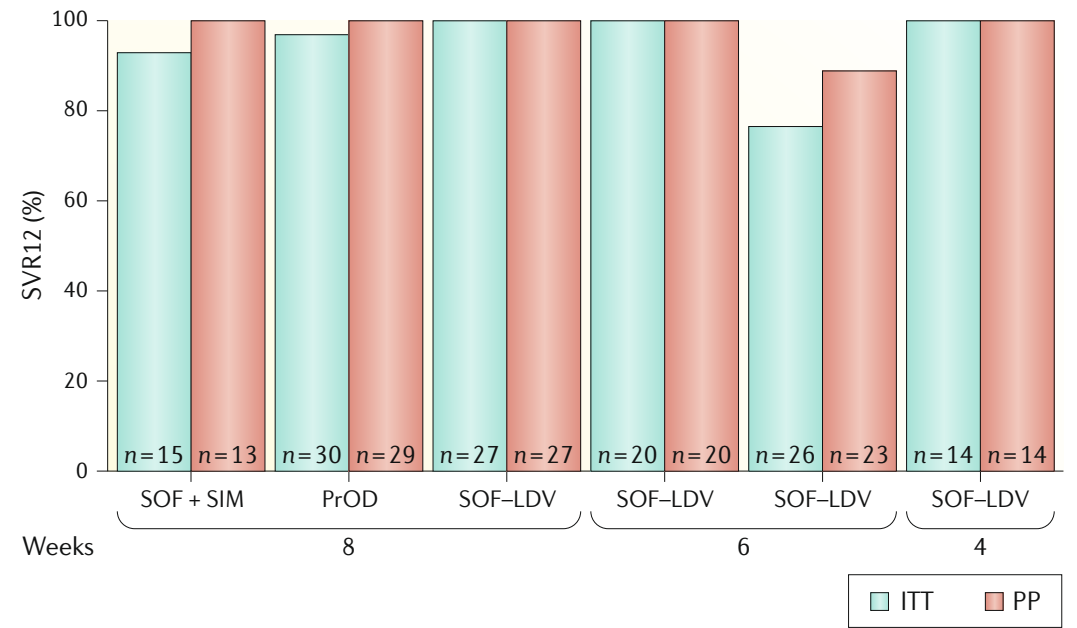

Fig. 2 | Efficacy of shortened duration direct-acting antiviral agent therapy in acute and recent HCV genotype 1 infection. The studies presented tested dual-class or triple-class direct-acting antiviral agent therapy in acute and recent HCV genotype 1 infection by intention-to-treat (ITT) and per-protocol (PP) analysis. PrOD, paritaprevirritonavir-ombitasvir and dasabuvir; SIM, simeprevir; SOF, sofosbuvir; SOF-LDV, sofosbuvir-ledipasvir; SVR12, SVR at 12 weeks. Data from REFS ${ }^{169,171,173}$.

pan-genotypic DAAs in well-characterized populations (including people with HIV infection or PWID) will be extremely valuable in determining the utility of DAAs in recent $\mathrm{HCV}$ infection. With high $\mathrm{HCV}$ infection incidence in populations of PWID and HIV-positive MSM, determining the optimal timing of treatment initiation, duration of therapy and regimen choice in recent infection is important (including for treatment of reinfection). If ultra-short duration therapy with an optimal DAA regimen is shown to be highly effective in individuals in the first year after infection acquisition, this finding will have major implications for screening and treatment strategies in high-risk populations.

\section{Reinfection after treatment}

One challenge to HCV elimination is reinfection. Higher HCV reinfection incidence after treatment in acute HCV cohorts (reinfection incidence 7.4-15.2 per 100 person-years) ${ }^{68,185-187}$ (TABLE 3) contrasts with the majority of published and preliminary studies among individuals treated for chronic $\mathrm{HCV}$ infection (reinfection incidence $0-5$ per 100 person-years) ${ }^{188-190}$. The risk of reinfection after treatment for both acute and chronic HCV infection is higher in those who report ongoing high-risk behaviour (such as continued injection drug use ${ }^{187,189,191-193}$, highlighting the need for post-treatment surveillance, rapid diagnosis of reinfection and access to re-treatment.

Although injecting risk behaviour among PWID seemed to decline following interferon-based treatment ${ }^{194-196}$, it is possible that expanded HCV treatment access and DAA therapeutic optimism might be associated with increased risk behaviour, as seen among MSM following the introduction of HIV combination antiretroviral therapy ${ }^{197}$. The incidence of HCV reinfection will require robust evaluation with sufficient follow-up time and HCV RNA testing at regular intervals. Although annual HCV
RNA testing is recommended to monitor at-risk individuals, the optimal interval (3, 6 or 12 months) for repeated HCV RNA testing requires investigation, as testing frequency will affect reinfection detection ${ }^{198}$. Routine post-treatment surveillance should ensure that reinfection is diagnosed within the first year of re-acquisition, which will have substantial implications for therapeutic strategies in recent $\mathrm{HCV}$ infection. Additionally, characterization of reinfection and the host-virus interplay in the setting of re-exposure might assist in vaccine development.

As DAA treatment scale-up expands among populations exhibiting ongoing risk behaviours for reacquisition (including recent PWID and HIV-positive MSM), acknowledgement that $\mathrm{HCV}$ reinfection can and will occur is essential. HCV reinfection prevention and management strategies should be incorporated into the individual-level and population-level $\mathrm{HCV}$ responses (BOX 3). Options include education and counselling ${ }^{199}$, optimal harm reduction ${ }^{36,46,53,58-60,62,65,200}$, treatment of the individual and their injecting (or sexual) partner or people in their network ${ }^{201}$, management of medical and psychiatric comorbidity ${ }^{62}$, post-treatment surveillance $\mathrm{e}^{202}$ and rapid re-treatment of reinfection. At a population level, universal access to care and treatment, political will, sufficient funding and alleviation of the stigma associated with $\mathrm{HCV}$ infection should assist in efforts to reduce $\mathrm{HCV}$ primary and reinfection incidence. Most importantly, re-treatment for reinfection should be offered without stigma or discrimination.

\section{HCV treatment as prevention}

The availability of DAAs has provided the therapeutic tools required to strive for $\mathrm{HCV}$ elimination and has stimulated discussion around HCV treatment as prevention ${ }^{8}$. To achieve elimination, strategies to curb transmission will be required. One approach to reduce transmission is improved diagnosis and treatment of recent $\mathrm{HCV}$ infection. Mathematical modelling suggests that substantial reductions in $\mathrm{HCV}$ incidence and prevalence can be achieved by targeted DAA treatment scale-up among those at highest risk of ongoing transmission, including PWID and HIV-positive MSM $^{11,203-206}$. Data from the UK Collaborative HIV Cohort predicted that the greatest effect on HCV incidence and prevalence would be achieved if DAA scale-up was prioritized to those with recently diagnosed ( $<1$ year) HCV infection and if it occurred in combination with behavioural interventions ${ }^{11}$. Despite the high cost of DAAs, treating recent PWID and HIV-positive MSM with early liver disease associated with $\mathrm{HCV}$ infection seems to be cost-effective given the reduction in liver-related complications and additional benefit of averting secondary infections ${ }^{9,207,208}$. In jurisdictions with universal access to DAAs, encouraging initial reports highlight high DAA uptake among HIV-positive MSM, with corresponding reductions in HCV viraemic prevalence ${ }^{209,210}$ and incidence ${ }^{209}$. Modelling estimates and real-world data support broad access to DAAs, without limitations based on duration of infection, disease stage or drug use, to gain the greatest individual-level and population-level benefits. 
Table $3 \mid \mathrm{HCV}$ reinfection after treatment for acute and recent HCV infection

\begin{tabular}{|c|c|c|c|c|c|c|}
\hline Author, year & $\begin{array}{l}\text { Study population } \\
\text { (\% total study } \\
\text { population) }\end{array}$ & Location, study design & $n$ & $\begin{array}{l}\text { Reinfection } \\
\text { (n) }\end{array}$ & PYFU & $\begin{array}{l}\text { Reinfection } \\
\text { incidence per } \\
100 \text { person-years } \\
(95 \% \mathrm{Cl})\end{array}$ \\
\hline \multicolumn{7}{|l|}{ Meta-analyses } \\
\hline $\begin{array}{l}\text { Hagan, } 2015 \\
\left(\text { REF. }^{68}\right)\end{array}$ & $\begin{array}{l}\text { HIV-positive MSM } \\
(100 \%)\end{array}$ & $\begin{array}{l}\text { NA, meta-analysis } \\
\text { (pooled results of two studies) }\end{array}$ & 170 & 38 & NA & $11.4(7.4-17.7)$ \\
\hline \multicolumn{7}{|l|}{ Primary studies } \\
\hline $\begin{array}{l}\text { Lambers }^{\mathrm{a}} \text {, } \\
2011 \text { (REF. }^{185} \text { ) }\end{array}$ & $\begin{array}{l}\text { HIV-positive MSM } \\
(100 \%)\end{array}$ & Netherlands, retrospective & 56 & 11 & 72 & $15.2(8.0-26.5)$ \\
\hline $\begin{array}{l}\text { Martin }{ }^{\mathrm{a}}, 2013 \\
\text { (REF. }{ }^{186} \text { ) }\end{array}$ & $\begin{array}{l}\text { HIV-positive MSM } \\
(100 \%)\end{array}$ & England, retrospective & 114 & 27 & NA & $9.6(6.6-14.1)$ \\
\hline $\begin{array}{l}\text { Vanhommerig, } \\
2014 \text { (REF. } 232 \text { ) }\end{array}$ & $\begin{array}{l}\text { HIV-positive MSM } \\
(100 \%)\end{array}$ & Netherlands, prospective & 35 & 16 & NA & NA \\
\hline $\begin{array}{l}\text { Martinello, } \\
2017 \text { (REF. }{ }^{187} \text { ) }\end{array}$ & $\begin{array}{l}\text { HIV-positive MSM } \\
\text { (53\%) and recent } \\
\text { PWID (49\%) }\end{array}$ & Australia, prospective & 120 & 10 & 135 & $7.4(4.0-13.8)$ \\
\hline
\end{tabular}

MSM, men who have sex with men; NA, not available; PWID, people who inject drugs; PY, person-years; PYFU, person-years follow-up. ${ }^{\text {a }}$ tudies included in the meta-analysis performed by Hagan et al. ${ }^{68}$.

\section{Recommendations}

Management of recent $\mathrm{HCV}$ infection in the era of DAAs. Interferon-free DAA therapy is not currently approved by regulatory authorities for use in acute $\mathrm{HCV}$ infection. Although encouraging results following short duration therapy have been obtained in small cohorts $^{169,170}$, enrolment in prospective clinical trials is recommended to confirm this strategy. Pending the results of these clinical trials, people with acute HCV infection might be considered for treatment with the same DAA regimens as recommended for chronic HCV infection. Monitoring HCV RNA titres for 4-12 weeks following diagnosis of acute infection provides an opportunity to assess for spontaneous clearance before treatment initiation ${ }^{156-158}$. Given the individual-level and population-level benefits, access to HCV care and treatment for people at high risk of onward transmission, including those with recent HCV infection, should be a priority ${ }^{8}$.

Screening strategies in high-risk populations. Greater $\mathrm{HCV}$ testing (increasing access as well as regular testing and follow-up), diagnosis and linkage to care are required to facilitate DAA treatment scale-up. All PWID and HIV-positive MSM should be screened for

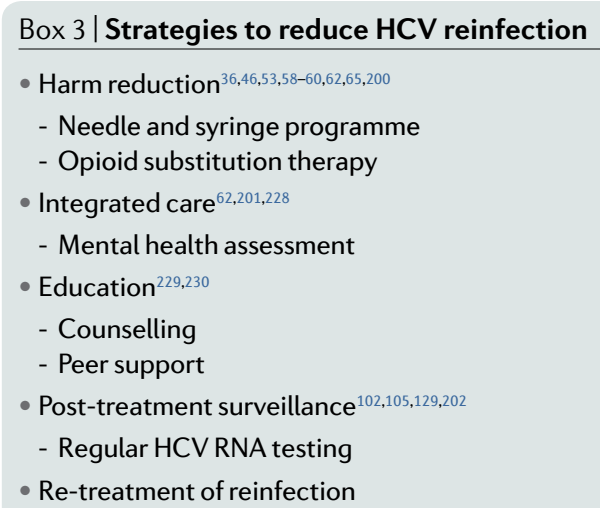

\section{Box 3 | Strategies to reduce HCV reinfection}

HCV infection with anti-HCV antibody ${ }^{102,105,129,130}$. In the context of ongoing risk behaviour (injection drug use and/or high-risk sexual behaviour), anti-HCV antibody screening every $6-12$ months should be performed to assess for incident infection ${ }^{102,105,129}$, with supplemental testing following potential exposure ${ }^{130}$. Assessment of HCV viraemia with HCV RNA should occur if there is high clinical suspicion, if transaminase (particularly ALT) levels are elevated or if HCV reinfection is suspected. Screening protocols for recent $\mathrm{HCV}$ infection in specific high-risk populations, including young PWID ${ }^{55,139,211}$, PWID in incarceration ${ }^{41,212}$ and HIV-positive MSM $^{69,213}$, should be considered ${ }^{214,215}$, potentially utilizing rapid or point-of-care diagnostics ${ }^{118,119,121,216}$, to improve HCV diagnosis, prevention and surveillance.

\section{Conclusions}

The advent of highly effective, well-tolerated interferon-free DAA therapy has revolutionized HCV therapeutics ${ }^{16}$. Combining two or more potent DAAs from different classes has increased SVR $(>90 \%)$ and shortened treatment duration to only 8-12 weeks in most populations with chronic $\mathrm{HCV}$ infection. Excellent results in chronic HCV infection have lessened the potential 'efficacy advantage' of early treatment initiation in acute HCV infection, but diagnosis and treatment of recent $\mathrm{HCV}$ infection should facilitate engagement in multidisciplinary care, prevent the development and complications of chronic liver disease and curb ongoing transmission in key populations. The role of ultra-short duration DAA therapy in recent $\mathrm{HCV}$ infection requires further evaluation.

The burden of disease attributed to HCV is high among PWID and is increasing among HIV-infected MSM. The potential for broad access, rapid DAA treatment scale-up and further treatment simplification has stimulated discussion around $\mathrm{HCV}$ treatment as prevention and $\mathrm{HCV}$ elimination ${ }^{8}$. HCV treatment as prevention strategies will be improved by early 
diagnosis and increased treatment uptake in recent HCV infection ${ }^{11,203}$. Ultimately, the population-level effects of DAA therapy will relate to facilitating global access to HCV screening, care and treatment ${ }^{217}$. The risk of HCV reinfection following treatment in individuals with ongoing behaviour facilitating HCV transmission emphasizes the need for post-treatment surveillance, harm reduction strategies and education but must not be considered an impediment to treatment if $\mathrm{HCV}$ elimination is to be achieved.

Published online 17 May 2018
1. World Health Organization. Global Hepatitis Report 2017. (WHO, Geneva, 2017)

2. Blach, S. et al. Global prevalence and genotype distribution of hepatitis C virus infection in 2015: a modelling study. Lancet Gastroenterol. Hepatol. 2, 161-176 (2017).

3. Nelson, P. K. et al. Global epidemiology of hepatitis B and hepatitis $C$ in people who inject drugs: results of systematic reviews. Lancet 378, 571-583 (2011).

4. Jordan, A. E. et al. Prevalence of hepatitis $C$ virus infection among HIV+ men who have sex with men: a systematic review and meta-analysis. Int. J. STD AIDS 28, 145-159 (2017).

5. Thursz, M. \& Fontanet, A. HCV transmission in industrialized countries and resource-constrained areas. Nat. Rev. Gastroenterol. Hepatol. 11, 28-35 (2014).

6. World Health Organization. Global Health Sector Strategy On Viral Hepatitis 2016-2021 (WHO, Geneva, 2016)

7. United Nations General Assembly. Transforming our world: the 2030 Agenda for Sustainable Development. UN Sustainable Development Knowledge Platform https://sustainabledevelopment. un.org/post2015/transformingourworld (2015).

8. Hajarizadeh, B et al. Hepatitis C treatment as prevention: evidence, feasibility, and challenges. Lancet Gastroenterol. Hepatol. 1, 317-327 (2016).

9. Martin, N. K. et al. Prioritization of HCV treatment in the direct-acting antiviral era: an economic evaluation J. Hepatol. 65, 17-25 (2016).

10. Cousien, A. et al. Hepatitis $C$ treatment as prevention of viral transmission and liver-related morbidity in persons who inject drugs. Hepatology 63, 1090-1101 (2016).

11. Martin, N. K. et al. Can hepatitis C virus (HCV) direct-acting antiviral treatment as prevention reverse the HCV epidemic among men who have sex with men in the United Kingdom? Epidemiological and modeling insights. Clin. Infect. Dis. 62, 1072-1080 (2016).

12. Martin, N. K. et al. Hepatitis C virus treatment for prevention among people who inject drugs: modeling treatment scale-up in the age of direct-acting antivirals. Hepatology 58, 1598-1609 (2013)

13. Zeuzem, S. et al. Grazoprevir-elbasvir combination therapy for treatment-naive cirrhotic and noncirrhotic patients with chronic hepatitis C virus genotype 1,4 , or 6 infection: a randomized trial. Ann. Intern. Med. 163, 1-13 (2015)

14. Kowdley, K. V. et al. Ledipasvir and sofosbuvir for 8 or 12 weeks for chronic HCV without cirrhosis. N. Engl. J. Med. 370, 1879-1888 (2014).

15. Feld, J. J. et al. Sofosbuvir and Velpatasvir for HCV Genotype 1, 2, 4, 5, and 6 Infection. N. Engl. J. Med. 373, 2599-2607 (2015).

16. Gotte, M. \& Feld, J. J. Direct-acting antiviral agents for hepatitis C: structural and mechanistic insights. Nat. Rev. Gastroenterol. Hepatol. 13, 338-351 (2016).

17. Manns, M. P. et al. Hepatitis $C$ virus infection Nat. Rev. Dis. Primers 3, 17006 (2017).

18. Calleri, G. et al. A short course of pegylated interferon-alpha in acute HCV hepatitis. J. Viral Hepat. 14, 116-121 (2007).

19. Nomura, H. et al. Short-term interferon-alfa therapy for acute hepatitis $\mathrm{C}$ : a randomized controlled trial. Hepatology 39, 1213-1219 (2004).

20. Santantonio, T. et al. Acute hepatitis C: a 24-week course of pegylated interferon alpha- $2 b$ versus 12-week course of pegylated interferon alpha- $2 \mathrm{~b}$ alone or with ribavirin. Hepatology 59, 2101-2109 (2014).

21. De Rosa, F. G. et al. Dose-dependent and genotype-independent sustained virological response of a 12 week pegylated interferon alpha-2b treatment for acute hepatitis C. J. Antimicrob. Chemother. 57. 360-363 (2006)

22. Martinello, M. et al. Short duration response-guided treatment is effective for most individuals with recent hepatitis C infection: the ATAHC II and DARE-C I studies. Antivir. Ther. 21, 425-434 (2016).
23. McHutchison, J. G. et al. Interferon alfa- $2 b$ alone or in combination with ribavirin as initial treatment for chronic hepatitis C. N. Engl. J. Med. 339 , 1485-1492 (1998).

24. Fried, M. W. et al. Peginterferon alfa-2a plus ribavirin for chronic hepatitis C virus infection. N. Engl. J. Med. 347, 975-982 (2002).

25. Thrift, A. P., El-Serag, H. B. \& Kanwal, F. Global epidemiology and burden of HCV infection and HCV-related disease. Nat. Rev. Gastroenterol. Hepatol. 14, 122 (2016).

26. Hatzakis, A. et al. The present and future disease burden of hepatitis $\mathrm{C}$ virus $(\mathrm{HCV})$ infections with today's treatment paradigm - volume 2. J. Viral Hepat. 22 (Suppl. 1), 26-45 (2015)

27. Sibley, A. et al. The present and future disease burden of hepatitis C virus infections with today's treatment paradigm - volume 3. J. Viral Hepat. 22 (Suppl. 4), 21-41 (2015).

28. Mohsen, A. et al. Hepatitis $C$ virus acquisition among Egyptians: analysis of a 10-year surveillance of acute hepatitis C. Trop. Med. Int. Health 20, 89-97 (2015).

29. Midgard, H. et al. HCV epidemiology in high-risk groups and the risk of reinfection. J. Hepatol. 65 S33-S45 (2016).

30. Kalinina, O. et al. Shift in predominating subtype of $\mathrm{HCV}$ from $1 \mathrm{~b}$ to $3 \mathrm{a}$ in St. Petersburg mediated by increase in injecting drug use. J. Med. Virol. 65 , 517-524 (2001).

31. Degenhardt, L. et al. Global prevalence of injecting drug use and sociodemographic characteristics and prevalence of HIV, HBV, and HCV in people who inject drugs: a multistage systematic review. Lancet Global Health 5, e1192-e1207 (2017).

32. Hajarizadeh, B., Grebely, J. \& Dore, G. J. Epidemiology and natural history of HCV infection. Nat. Rev. Gastroenterol. Hepatol. 10, 553-562 (2013).

33. Clatts, M. C., Colon-Lopez, V., Giang le, M. \& Goldsamt, L. A. Prevalence and incidence of HCV infection among Vietnam heroin users with recent onset of injection. J. Urban Health 87, 278-291 (2010).

34. Spittal, P. M. et al. The Cedar Project: high incidence of HCV infections in a longitudinal study of young Aboriginal people who use drugs in two Canadian cities. BMC Public Health 12, 632 (2012).

35. Sacks-Davis, R. et al. High rates of hepatitis $C$ virus reinfection and spontaneous clearance of reinfection in people who inject drugs: a prospective cohort study. PLOS ONE 8, e80216 (2013).

36. Tsui, J. I., Evans, J. L., Lum, P. J., Hahn, J. A. \& Page, K. Association of opioid agonist therapy with lower incidence of hepatitis $C$ virus infection in young adult injection drug users. JAMA Intern. Med. 174 1974-1981 (2014).

37. Suryaprasad, A. G. et al. Emerging epidemic of hepatitis $C$ virus infections among young nonurban persons who inject drugs in the United States, 2006-2012. Clin. Infect. Dis. 59, 1411-1419 (2014).

38. Zibbell, J. E et al. Increases in hepatitis C virus infection related to injection drug use among persons aged $\leq 30$ years - Kentucky, Tennessee, Virginia, and West Virginia, 2006-2012. Morb. Mortal. Wkly Rep. 64, 453-458 (2015)

39. Snow, K. J., Young, J. T., Preen, D. B., Lennox, N. G. $\&$ Kinner, S. A. Incidence and correlates of hepatitis C virus infection in a large cohort of prisoners who have injected drugs. BMC Public Health 14, 830 (2014).

40. Luciani, F et al. A prospective study of hepatitis C incidence in Australian prisoners. Addiction 109. 1695-1706 (2014).

41. Larney, S. et al. Incidence and prevalence of hepatitis $C$ in prisons and other closed settings: results of a systematic review and meta-analysis. Hepatology $\mathbf{5 8}$, 1215-1224 (2013).

42. Cunningham, E. B. et al. Ongoing incident hepatitis $C$ virus infection among people with a history of injecting drug use in an Australian prison setting, 2005-2014: the HITS-p study. J. Viral Hepat. 24, 733-741 (2017)
43. Maher, L. et al. Incidence and risk factors for hepatitis $C$ seroconversion in injecting drug users in Australia. Addiction 101, 1499-1508 (2006).

44. Hagan, H., Pouget, E. R., Des Jarlais, D. C. \& Lelutiu-Weinberger, C. Meta-regression of hepatitis C virus infection in relation to time since onset of illicit drug injection: the influence of time and place. Am. J. Epidemiol. 168, 1099-1109 (2008).

45. Morris, M. D. et al. Geographic differences in temporal incidence trends of hepatitis $\mathrm{C}$ virus infection among people who inject drugs: the $\mathrm{InC} 3$ Collaboration. Clin. Infect. Dis. 64, 860-869 (2017).

46. Palmateer, N. E. et al. Rapid decline in HCV incidence among people who inject drugs associated with national scale-up in coverage of a combination of harm reduction interventions. PLOS ONE 9 , e104515 (2014)

47. Centers for Disease Control and Prevention. Notes from the Field: Risk factors for hepatitis $C$ virus infections among young adults - Massachusetts, 2010. Morb. Mortal. Wkly. Rep. 60, 1457-1458 (2011).

48. Centers for Disease Control and Prevention. Viral Hepatitis Surveillance - United States, 2014. CDC https://www.cdc.gov/hepatitis/statistics/ 2014surveillance/index.htm (2014).

49. Lepretre, A. et al. Prevalence and behavioural risks for HIV and HCV infections in a population of drug users of Dakar, Senegal: the ANRS 12243 UDSEN study. J. Int. AIDS Soc. 18, 19888 (2015).

50. Zibbell, J. E. et al. Increases in acute hepatitis C virus infection related to a growing opioid epidemic and associated injection drug use, United States, 2004 to 2014. Am. J. Public Health 108, 175-181 (2018).

51. Grebely, J. et al. Declining incidence of hepatitis C virus infection among people who inject drugs in a Canadian setting, 1996-2012. PLOS ONE 9, e97726 (2014).

52. van den Berg, C. H. et al. Major decline of hepatitis C virus incidence rate over two decades in a cohort of drug users. Eur. J. Epidemiol. 22, 183-193 (2007).

53. White, B., Dore, G. J., Lloyd, A. R., Rawlinson, W. D. \& Maher, L. Opioid substitution therapy protects against hepatitis $\mathrm{C}$ virus acquisition in people who inject drugs: the HITS-c study. Med. J. Aust. 201, 326-329 (2014).

54. Pouget, E. R., Hagan, H. \& Des Jarlais, D. C. Meta-analysis of hepatitis $C$ seroconversion in relation to shared syringes and drug preparation equipment. Addiction 107, 1057-1065 (2012)

55. Tracy, D. et al. Higher risk of incident hepatitis C virus among young women who inject drugs compared with young men in association with sexual relationships: a prospective analysis from the UFO Study cohort. BMJ Open 4, e004988 (2014).

56. Esmaeili, A. et al. Higher incidence of HCV in females compared to males who inject drugs: a systematic review and meta-analysis. J. Viral Hepat. 24, 117-127 (2017).

57. Evans, J. L. et al. Gender differences in sexual and injection risk behavior among active young injection drug users in San Francisco (the UFO Study). J. Urban Health 80, 137-146 (2003).

58. Nolan, S. et al. The impact of methadone maintenance therapy on hepatitis $\mathrm{C}$ incidence among illicit drug users. Addiction 109, 2053-2059 (2014).

59. Turner, K. M. et al. The impact of needle and syringe provision and opiate substitution therapy on the incidence of hepatitis $C$ virus in injecting drug users: pooling of UK evidence. Addiction 106, 1978-1988 (2011).

60. Allen, E. J. et al. Association between harm reduction intervention uptake and recent hepatitis $C$ infection among people who inject drugs attending sites that provide sterile injecting equipment in Scotland. Int. J. Drug Policy 23, 346-352 (2012).

61. Rodrigo, C. et al. Phylogenetic analysis of full-length, early infection, hepatitis $C$ virus genomes among people with intravenous drug use: the InC3 Study. J. Viral Hepat. 24, 43-52 (2017). 
62. Islam, N. et al. Incidence, risk factors, and prevention of hepatitis C reinfection: a population-based cohort study. Lancet Gastroenterol. Hepatol. 2, 200-210 (2017).

63. MacArthur, G. J. et al. Interventions to prevent HIV and Hepatitis $C$ in people who inject drugs: a review of reviews to assess evidence of effectiveness. Int. J. Drug Policy 25, 34-52 (2014).

64. Degenhardt, L. et al. Prevention of HIV infection for people who inject drugs: why individual, structural, and combination approaches are needed. Lancet 376 285-301 (2010)

65. Hagan, H. Pouget, E. R. \& Des Jarlais, D. C. A systematic review and meta-analysis of interventions to prevent hepatitis $C$ virus infection in people who inject drugs. J. Infect. Dis. 204, 74-83 (2011).

66. Platt, L. et al. Effectiveness of needle/syringe programmes and opiate substitution therapy in preventing HCV transmission among people who inject drugs. Cochrane Database Syst. Rev. 1, CD012021 (2016).

67. Platt, L. et al. Needle and syringe programmes and opioid substitution therapy for preventing HCV transmission among people who inject drugs: findings from a Cochrane Review and meta-analysis. Addiction 113, 545-563 (2018).

68. Hagan, H., Jordan, A. E., Neurer, J. \& Cleland, C. M Incidence of sexually transmitted hepatitis $C$ virus infection in HIV-positive men who have sex with men. AIDS 29, 2335-2345 (2015).

69. Wandeler, G. et al. Hepatitis C virus infections in the Swiss HIV Cohort Study: a rapidly evolving epidemic Clin. Infect. Dis. 55, 1408-1416 (2012).

70. Centers for Disease Control \& Prevention. Sexual transmission of hepatitis $C$ virus among HIV-infected men who have sex with men - New York City, 2005-2010. Morb. Mortal. Wkly. Rep. 60, 945-950 (2011).

71. van de Laar, T. et al. Evidence of a large, international network of HCV transmission in HIV-positive men who have sex with men. Gastroenterology 136 1609-1617 (2009).

72. Gamage, D. G. et al. Incidence of hepatitis-C among HIV infected men who have sex with men (MSM) attending a sexual health service: a cohort study. BMC Infect. Dis. 11, 39 (2011)

73. Gambotti, L. et al. Acute hepatitis $C$ infection in HIV positive men who have sex with men in Paris, France, 2001-2004. Eurosurveillance 10, 115-117 (2005).

74. Danta, M. et al. Recent epidemic of acute hepatitis $C$ virus in HIV-positive men who have sex with men linked to high-risk sexual behaviours. AIDS $\mathbf{2 1}$ 983-991 (2007).

75. Sun, $\mathrm{H}$. Y. et al. Recent hepatitis $\mathrm{C}$ virus infections in HIV-infected patients in Taiwan: incidence and risk factors. J. Clin. Microbiol. 50, 781-787 (2012).

76. Nishijima, T. et al. Incidence and risk factors for incident Hepatitis $C$ infection among men who have sex with men with HIV-1 infection in a large Urban HIV clinic in Tokyo. J. Acquir. Immune Defic. Syndr. 65 213-217 (2014)

77. Witt, M. D. et al. Incident hepatitis C virus infection in men who have sex with men: a prospective cohort analysis, 1984-2011. Clin. Infect. Dis. 57, 77-84 (2013)

78. Boesecke, C. et al. Hepatitis C seroconversions in HIV infection across Europe: which regions and patient groups are affected? Liver Int. 35, 2384-2391 (2015).

79. Platt, L. et al. Prevalence and burden of HCV co-infection in people living with HIV: a global systematic review and meta-analysis. Lancet Infect. Dis. 16, 797-808 (2016)

80. Sobrino-Vegas, $\mathrm{P}$ et al. Incidence of hepatitis $\mathrm{C}$ virus (HCV) in a multicenter cohort of HIV-positive patients in Spain 2004-2011: increasing rates of HCV diagnosis but not of HCV seroconversions. PLOS ONE 9, e116226 (2014)

81. Hasse, B. et al. Frequency and determinants of unprotected sex among HIV-infected persons: the Swiss HIV cohort study. Clin. Infect. Dis. $\mathbf{5 1}$ 1314-1322 (2010)

82. Breskin, A. et al. Factors associated with hepatitis C Infection among HIV-infected men who have sex with men with no reported injection drug use in New York City, 2000-2010. Sex. Transm. Dis. 42, 382-386 (2015).

83. Apers, L. et al. Risk factors for $\mathrm{HCV}$ acquisition among HIV-positive MSM in Belgium. J. Acquir. Immune Defic. Syndr. 68, 585-593 (2015).

84. Khosropour, C. M. et al. Trends in serosorting and the association with HIV/STI risk over time among men who have sex with men (MSM). J. Acquir. Immune Defic. Syndr. 72, 189-197 (2016).
85. Velter, A. et al. Sexual and prevention practices in men who have sex with men in the era of combination HIV prevention: results from the Presse Gays et Lesbiennes survey, France, 2011. Eurosurveillance 20, 21090 (2015).

86. Melendez-Torres, G. J. \& Bourne, A. Illicit drug use and its association with sexual risk behaviour among MSM: more questions than answers? Curr. Opin. Infect. Dis. 29, 58-63 (2016).

87. Gilbart, V. L. et al. Sex, drugs and smart phone applications: findings from semistructured interviews with men who have sex with men diagnosed with Shigella flexneri $3 a$ in England and Wales. Sex. Transm. Infect. 91, 598-602 (2015).

88. Hoornenborg, E. et al. Men who have sex with men starting pre-exposure prophylaxis (PrEP) are at risk of $\mathrm{HCV}$ infection: evidence from the Amsterdam PrEP study. AIDS 31, 1603-16010 (2017).

89. Ward, C. \& Lee, V. Should we offer routine hepatitis C antibody testing in men who have sex with men? J. Int. AIDS Soc. 17, 19591 (2014)

90. Yaphe, $S$. et al. Incidence of acute hepatitis $C$ virus infection among men who have sex with men with and without HIV infection: a systematic review. Sex. Transm. Infect. 88, 558-564 (2012)

91. Jin, F. et al. Prevalence, incidence and risk factors for hepatitis $C$ in homosexual men: data from two cohorts of HIV-negative and HIV-positive men in Sydney, Australia. Sex. Transm. Infect. 86, 25-28 (2010)

92. Volk, J. E., Marcus, J. L., Phengrasamy, T. \& Hare, C. B. Incident hepatitis $C$ virus infections among users of HIV preexposure prophylaxis in a clinical practice setting. Clin. Infect. Dis. 60, 1728-1729 (2015).

93. Golub, S. A., Kowalczyk, W., Weinberger, C. L. $\delta$ Parsons, J. T. Preexposure prophylaxis and predicted condom use among high-risk men who have sex with men. J. Acquir. Immune Defic. Syndr. 54, 548-555 (2010).

94. McFaul, K. et al. Acute hepatitis $C$ infection in HIV-negative men who have sex with men. J. Viral Hepat. 22, 535-538 (2015)

95. Molina, J. M. et al. On-demand preexposure prophylaxis in men at high risk for HIV-1 infection. N. Engl. J. Med. 373, 2237-2246 (2015).

96. McCormack, S. et al. Pre-exposure prophylaxis to prevent the acquisition of HIV-1 infection (PROUD): effectiveness results from the pilot phase of a pragmatic open-label randomised trial. Lancet 387 53-60 (2016)

97. Khan, A. J. et al. Unsafe injections and the transmission of hepatitis B and C in a periurban community in Pakistan. Bull. World Health Organiz. 78, 956-963 (2000)

98. Pepin, J., Abou Chakra, C. N., Pepin, E., Nault, V. \& Valiquette, L. Evolution of the global burden of viral infections from unsafe medical injections, 2000-2010. PLoS ONE 9, e99677 (2014).

99. Su, Y., Norris, J. L., Zang, C., Peng, Z. \& Wang, N. Incidence of hepatitis $C$ virus infection in patients on hemodialysis: a systematic review and meta-analysis. Hemodialysis Int. 17, 532-541 (2013)

100. Saune, K. et al. Decreased prevalence and incidence of HCV markers in haemodialysis units: a multicentric French survey. Nephrol. Dial. Transplant. 26, 2309-2316 (2011)

101. Fabrizi, F. \& Messa, P. Transmission of hepatitis C virus in dialysis units: a systematic review of reports on outbreaks. Int. J. Artif. Organs 38, 471-480 (2015).

102. AASLD-IDSA. HCV Guidance: Recommendations for Testing, Managing, and Treating Hepatitis C. HCVguidelines.org http://www.hcvguidelines.org/ (2016).

103. Hajarizadeh, B., Grebely, J. \& Dore, G. J. Case definitions for acute hepatitis $C$ virus infection: a systematic review. J. Hepatol. 57, 1349-1360 (2012).

104. Centers for Disease Control and Prevention. Hepatitis C Acute: 2016 Case Definition. CDC https:// wwwn.cdc.gov/nndss/conditions/hepatitis-c-acute/ case-definition/2016/ (2016)

105. European Association for the Study of the Liver. EASL Recommendations on Treatment of Hepatitis C 2016. J. Hepatol. 66, 153-194 (2017)

106. Orland, J. R., Wright, T. L. \& Cooper, S. Acute hepatitis C. Hepatology 33, 321-327 (2001)

107. Netski, D. M. et al. Humoral immune response in acute hepatitis C virus infection. Clin. Infect. Dis. $\mathbf{4 1}$ 667-675 (2005).

108. Preiksaitis, J. K., Cockfield, S. M., Fenton, J. M., Burton, N. I. \& Chui, L. W. Serologic responses to hepatitis $\mathrm{C}$ virus in solid organ transplant recipients. Transplantation 64, 1775-1780 (1997).
109. Schroeter, M., Zoellner, B., Polywka, S., Laufs, R. \& Feucht, H. H. Prolonged time until seroconversion among hemodialysis patients: the need for HCV PCR. Intervirology 48, 213-215 (2005).

110. Thomson, E. C. et al. Delayed anti-HCV antibody response in HIV-positive men acutely infected with HCV. AIDS 23, 89-93 (2009).

111. Kamili, S., Drobeniuc, J., Araujo, A. C. \& Hayden, T. M. Laboratory diagnostics for hepatitis $C$ virus infection. Clin. Infect. Dis. 55, S43-S48 (2012)

112. McGovern, B. H. et al. Improving the diagnosis of acute hepatitis $C$ virus infection with expanded viral load criteria. Clin. Infect. Dis. 49, 1051-1060 (2009).

113. Hajarizadeh, B. et al. Patterns of hepatitis C virus RNA levels during acute infection: the $\operatorname{lnC}^{3}$ study. PLOS ONE 10, e0122232 (2015).

114. Freiman, J. M. et al. HCV core antigen testing for diagnosis of HCV infection: a systematic review and meta-analysis. Ann. Intern. Med. 165, 345-355 (2016).

115. Hullegie, S. J., GeurtsvanKessel, C. H., van der Eijk, A. A., Ramakers, C \& Rijnders, B. J. A. HCV antigen instead of RNA testing to diagnose acute $\mathrm{HCV}$ in patients treated in the Dutch Acute HCV in HIV Study. J. Int. AIDS Soc. 20, 1-3 (2017)

116. Drobnik, A. et al. Public health implications of rapid hepatitis $C$ screening with an oral swab for community-based organizations serving high-risk populations. Am. J. Public Health 101, 2151-2155 (2011)

117. Jewett, A. et al. Field-based performance of three pre-market rapid hepatitis $\mathrm{C}$ virus antibody assays in STAHR (Study to Assess Hepatitis C Risk) among young adults who inject drugs in San Diego, CA. J. Clin. Virol. 54, 213-217 (2012).

118. Smith, B. D. et al. Performance of premarket rapid hepatitis $C$ virus antibody assays in 4 national human immunodeficiency virus behavioral surveillance system sites. Clin. Infect. Dis. 53, 780-786 (2011).

119. Smith, B. D. et al. Evaluation of three rapid screening assays for detection of antibodies to hepatitis $C$ virus. J. Infect. Dis. 204, 825-831 (2011).

120. Shivkumar, S., Peeling, R., Jafari, Y., Joseph, L. \& Pant Pai, N. Accuracy of rapid and point-of-care screening tests for hepatitis $\mathrm{C}$ : a systematic review and meta-analysis. Ann. Intern. Med. 157, 558-566 (2012)

121. Wong, V. W. et al. Targeted hepatitis C screening among ex-injection drug users in the community. J. Gastroenterol. Hepatol. 29, 116-120 (2014).

122. Poiteau, L. et al. Performance of rapid diagnostic tests for the detection of antibodies to hepatitis $C$ virus in whole blood collected on dried blood spots. J. Viral Hepat. 23, 399-401 (2016).

123. McHugh, M. P. et al. Multicenter evaluation of the Cepheid Xpert Hepatitis C Virus Viral Load Assay. J. Clin. Microbiol. 55, 1550-1556 (2017).

124. Gupta, E., Agarwala, P., Kumar, G., Maiwall, R. \& Sarin, S. K. Point-of-care testing (POCT) in molecular diagnostics:performance evaluation of GeneXpert HCV RNA test in diagnosing and monitoring of $\mathrm{HCV}$ infection. J. Clin. Virol. 88, 46-51 (2017)

125. Grebely, J. et al. Evaluation of the Xpert HCV Viral Load point-of-care assay from venepuncture-collected and finger-stick capillary whole-blood samples: a cohort study. Lancet Gastroenterol. Hepatol. 2 , 514-520 (2017)

126. Lamoury, F. M. J. et al. Evaluation of the Xpert ${ }^{\circledast}$ HCV Viral Load Fingerstick point-of-care assay. J. Infect. Dis. https://doi.org/10.1093/infdis/jiy114 (2018).

127. Moyer, V. A. U.S. Preventive Services Task Force. Screening for hepatitis C virus infection in adults: U.S. Preventive Services Task Force recommendation statement. Ann. Intern. Med. 159, 349-357 (2013).

128. World Health Organization. Guidelines on Hepatitis $B$ and C Testing (WHO, Geneva, 2017).

129. Grebely, J. et al. Recommendations for the management of hepatitis $C$ virus infection among people who inject drugs. Int. J. Drug Policy 26, 1028-1038 (2015).

130. European AIDS Treatment Network (NEAT) Acute Hepatitis C Infection Consensus Panel. Acute hepatitis $\mathrm{C}$ in HIV-infected individuals: recommendations from the European AIDS Treatment Network (NEAT) consensus conference. AIDS 25, 399-409 (2011).

131. Grebely, J. et al. Hepatitis $C$ virus reinfection and superinfection among treated and untreated participants with recent infection. Hepatology 55 1058-1069 (2012).

132. Micallef, J. M., Kaldor, J. M. \& Dore, G. J. Spontaneous viral clearance following acute hepatitis $C$ infection: a systematic review of longitudinal studies. J. Viral Hepat. 13, 34-41 (2006)

133. Ingiliz, P. et al. HCV reinfection incidence and spontaneous clearance rates in HIV-positive men who 
have sex with men in Western Europe. J. Hepatol. 66, 282-287 (2017)

134. Thomson, E. C., Smith, J. A. \& Klenerman, P. The natural history of early hepatitis $C$ virus evolution; lessons from a global outbreak in human immunodeficiency virus-1-infected individuals. J. Gen. Virol. 92, 2227-2236 (2011).

135. Bowen, D. G. \& Walker, C. M. Adaptive immune responses in acute and chronic hepatitis $C$ virus infection. Nature 436, 946-952 (2005).

136. Grebely, J. et al. The effects of female sex, viral genotype, and IL28B genotype on spontaneous clearance of acute hepatitis $C$ virus infection. Hepatology 59, 109-120 (2014)

137. Hajarizadeh, B. et al. Dynamics of HCV RNA levels during acute hepatitis $\mathrm{C}$ virus infection. J. Med. Virol. 86, 1722-1729 (2014)

138. Grebely, J., Matthews, G. V., Petoumenos, K. \& Dore, G. J. Spontaneous clearance and the beneficial impact of treatment on clearance during recent hepatitis C virus infection. J. Viral Hepat. 17, 896 (2010).

139. Page, K. et al. Acute hepatitis $C$ virus infection in young adult injection drug users: a prospective study of incident infection, resolution, and reinfection J. Infect. Dis. 200, 1216-1226 (2009).

140. Cho, Y. K., Kim, Y. N. \& Song, B. C. Predictors of spontaneous viral clearance and outcomes of acute hepatitis C infection. Clin. Mol. Hepatol. 20, 368-375 (2014).

141. Thomson, E. C. et al. Predicting spontaneous clearance of acute hepatitis $C$ virus in a large cohort of HIV-1-infected men. Gut 60, 837-845 (2011).

142. Schulze Zur Wiesch, J. et al. Broadly directed virus-specific CD4+ T cell responses are primed during acute hepatitis $C$ infection, but rapidly disappear from human blood with viral persistence. J. Exp. Med. 209 61-75 (2012).

143. Lucas, M. et al. Tracking virus-specific CD4+ T cells during and after acute hepatitis $C$ virus infection. PLOS ONE 2, e649 (2007)

144. Gauthiez, E. et al. A systematic review and meta-analysis of HCV clearance. Liver Int. 37, 1431-1445 (2017).

145. Villano, S. A., Vlahov, D., Nelson, K. E., Cohn, S. \& Thomas, D. L. Persistence of viremia and the importance of long-term follow-up after acute hepatitis C infection. Hepatology 29, 908-914 (1999).

146. Thomas, D. L. et al. The natural history of hepatitis C virus infection: host, viral, and environmental factors. JAMA 284, 450-456 (2000).

147. Liu, L., Fisher, B., Thomas, D., Cox, A. \& Ray, S. Spontaneous clearance of primary acute hepatitis C virus infection correlated with high initial viral RNA level and rapid HVR 1 evolution. Hepatology 55 , 1684-1691 (2012)

148. Bull, R. A. et al. Sequential bottlenecks drive viral evolution in early acute hepatitis $\mathrm{C}$ virus infection PLoS Pathog. 7, e 1002243 (2011).

149. Gutierrez-Moreno, M. et al. Spontaneous clearance of $\mathrm{HCV}$ in HIV-hepatitis $\mathrm{C}$ virus coinfected liver transplant patients: prospective study. Transplant. Proc. 44, 2100-2102 (2012)

150. Dale, C. H., Burns, P., McCutcheon, M., Hernandez-Alejandro, R. \& Marotta, P. J. Spontaneous clearance of hepatitis $C$ after liver and renal transplantation. Can. J. Gastroenterol. 23, 265-267 (2009).

151. Soriano, V. et al. Spontaneous viral clearance, viral load, and genotype distribution of hepatitis $C$ virus (HCV) in HIV-infected patients with anti-HCV antibodies in Europe. J. Infect. Dis. 198, 1337-1344 (2008).

152. Webster, D. P. et al. Spontaneous clearance and treatment of acute hepatitis C infection in HIV-positive men with 48 weeks of interferon-alpha and ribavirin. Int. J. STD AIDS 24, 179-183 (2013).

153. Smith, D. J., Jordan, A. E., Frank, M. \& Hagan, H. Spontaneous viral clearance of hepatitis C virus (HCV) infection among people who inject drugs (PWID) and HIV-positive men who have sex with men (HIV+ MSM) : a systematic review and meta-analysis. BMC Infect. Dis. 16, 471 (2016)

154. Shin, E.-C., Sung, P. S. \& Park, S.-H. Immune responses and immunopathology in acute and chronic viral hepatitis. Nat Rev Immunol 16, 509-523 (2016).

155. Park, S. H. \& Rehermann, B. Immune responses to $\mathrm{HCV}$ and other hepatitis viruses. Immunity 40, 13-24 (2014).

156. Deterding, K. et al. Delayed versus immediate treatment for patients with acute hepatitis $\mathrm{C}$ : a randomised controlled non-inferiority trial. Lancet Infect. Dis. 13, 497-506 (2013).

157. Corey, K. E., Mendez-Navarro, J., Gorospe, E. C., Zheng, H. \& Chung, R. T. Early treatment improves outcomes in acute hepatitis $C$ virus infection: a meta-analysis. J. Viral Hepat. 17, 201-207 (2010).

158. Vogel, M., Boesecke, C. \& Rockstroh, J. K. Acute hepatitis $C$ infection in HIV-positive patients. Curr. Opin. Infect. Dis. 24, 1-6 (2011).

159. Dorward, J. et al. Successful treatment of acute hepatitis $\mathrm{C}$ virus in HIV positive patients using the European AIDS Treatment Network guidelines for treatment duration. J. Clin. Virol. 52, 367-369 (2011)

160. European AIDS Clinical Society. EACS Guidelines 8.2 2017 (EACS, 2017)

161. Naggie, S., Holland, D. P., Sulkowski, M. S. \& Thomas, D. L. Hepatitis C virus postexposure prophylaxis in the healthcare worker: why direct-acting antivirals don't change a thing. Clin. Infect. Dis. 64, 92-99 (2017).

162. Jaeckel, E. et al. Treatment of acute hepatitis $C$ with interferon alfa-2b. N. Engl. J. Med. 345, 1452-1457 (2001).

163. Santantonio, T. et al. Efficacy of a 24-week course of PEG-interferon alpha- $2 \mathrm{~b}$ monotherapy in patients with acute hepatitis $\mathrm{C}$ after failure of spontaneous clearance. J. Hepatol. 42, 329-333 (2005)

164. Delwaide, J. et al. Treatment of acute hepatitis $C$ with interferon alpha- $2 \mathrm{~b}$ : early initiation of treatment is the most effective predictive factor of sustained viral response. Aliment. Pharmacol. Ther. 20, 15-22 (2004).

165 . Wiegand, J. et al. Early monotherapy with pegylated interferon alpha- $2 \mathrm{~b}$ for acute hepatitis $\mathrm{C}$ infection the HEP-NET acute-HCV-II study. Hepatology 43 250-256 (2006)

166. Dore, G. J. et al. Effective treatment of injecting drug users with recently acquired hepatitis $C$ virus infection. Gastroenterology 138, 123-135 (2010).

167. Martinello, M. et al. Sofosbuvir and ribavirin for 6 weeks is not effective among people with recent hepatitis $C$ virus infection: the DARE-C II study. Hepatology 64, 1911-1921 (2016).

168. Naggie, S. et al. Sofosbuvir plus ribavirin without interferon for treatment of acute hepatitis $C$ virus infection in HIV-1-infected individuals: SWIFT-C. Clin. Infect. Dis. 64, 1035-1042 (2017).

169. Deterding, K. et al. Ledipasvir plus sofosbuvir fixed-dose combination for 6 weeks in patients with acute hepatitis $C$ virus genotype 1 monoinfection (HepNet Acute HCV IV): an open-label, single-arm, phase 2 study. Lancet Infect. Dis. 17, 215-222 (2017).

170. Basu, P., Shah, N. J., John, N., Aloysius, M. \& Brown, R Sofosbuvir and ledipasvir in attainment of SVR12 in sickle cell disease (SCD) sub-population with chronic hepatitis $\mathrm{C}(\mathrm{CHC})$. A single center prospective open label clinical pilot study - SLASH C Trial [abstract]. Hepatology 62 (Suppl), 1037 (2015).

171. Naggie, S. et al. $100 \%$ SVR with 8 weeks of ledipasvir sofosbuvir in HIV-infected men with acute HCV infection: results from the SWIFT-C trial [abstract] Hepatology 66 (Suppl.), 196 (2017).

172. Martinello, M. et al. Shortened therapy of eight weeks with paritaprevir/ritonavir/ombitasvir and dasabuvir is highly effective in people with recent HCV genotype 1 infection. J. Viral Hepat. https://doi.org/10.1111/ jvh.12917 (2018).

173. Rockstroh, J. K. et al. Ledipasvir-sofosbuvir for 6 weeks to treat acute HCV genotype 1 or 4 infection in patients coinfected with HIV-1: an open-label study. Lancet Gastroenterol. Hepatol. 2, 347-353 (2017).

174. Dahari, H. et al. HCV kinetic and modeling analyses indicate similar time to cure among sofosbuvir combination regimens with daclatasvir, simeprevir or ledipasvir. J. Hepatol. 64, 1232-1239 (2016).

175. Rockstroh, J. K. et al. Ledipasvir-sofosbuvir for 6 weeks to treat acute hepatitis $C$ virus genotype 1 or 4 infection in patients with HIV coinfection: an open-label, single-arm trial. Lancet Gastroenterol. Hepatol. 2, 347-353 (2017)

176. Lawitz, E. et al. Short-duration treatment with elbasvir/grazoprevir and sofosbuvir for hepatitis C: A randomized trial. Hepatology 65, 439-450 (2017).

177. Terrault, N. A. et al. Effectiveness of ledipasvir-sofosbuvir combination in patients with hepatitis $\mathrm{C}$ virus infection and factors associated of sustained virologic response. Gastroenterology 151, 1131-1140.e5 (2016).

178. O'Brien, T. R., Feld, J. J. Kottilil, S. \& Pfeiffer, R. M. No scientific basis to restrict 8 weeks of treatment with ledipasvir/sofosbuvir to patients with hepatitis $C$ virus RNA $<6,000,000 \mathrm{lU} / \mathrm{mL}$ Hepatology 63, 28-30 (2016).

179. Lau, G. et al. Efficacy and safety of 3-week response-guided triple direct-acting antiviral therapy for chronic hepatitis C infection: a phase 2, open-label, proof-of-concept study. Lancet Gastroenterol. Hepatol. 1, 97-104 (2016).
180. Perelson, A. S. \& Guedj, J. Modelling hepatitis C therapy - predicting effects of treatment. Nat. Rev. Gastroenterol. Hepatol. 12, 437-445 (2015).

181. Guedj, J. \& Perelson, A. S. Second-phase hepatitis C virus RNA decline during telaprevir-based therapy increases with drug effectiveness: implications for treatment duration. Hepatology 53, 1801-1808 (2011).

182. Bethea, E. D., Chen, Q., Hur, C., Chung, R. T. \& Chhatwal, J. Should we treat acute hepatitis C? A decision and cost-effectiveness analysis. Hepatology 67, 837-846 (2018)

183. Dill, M. T. et al. Interferon-gamma-stimulated genes, but not USP18, are expressed in livers of patients with acute hepatitis C. Gastroenterology 143, 777-786. e6 (2012).

184. Kwo, P. Y. et al. Glecaprevir and pibrentasvir yield high response rates in patients with HCV genotype 1-6 without cirrhosis. J. Hepatol. 67, 263-271 (2017).

185. Lambers, F. A. et al. Alarming incidence of hepatitis C virus re-infection after treatment of sexually acquired acute hepatitis C virus infection in HIV-infected MSM. AIDS 25, F21-F27 (2011).

186. Martin, T. C. et al. Hepatitis C virus reinfection incidence and treatment outcome among HIV-positive MSM. AIDS 27, 2551-2557 (2013).

187. Martinello, M. et al. HCV reinfection incidence among individuals treated for recent infection. J. Viral Hepat. 24, 359-370 (2017)

188. Simmons, B., Saleem, J., Hill, A., Riley, R. D. \& Cooke, G. S. Risk of late relapse or reinfection with hepatitis $C$ virus after achieving a sustained virological response: a systematic review and meta-analysis. Clin. Infect. Dis. 62, 683-694 (2016).

189. Aspinall, E. J. et al. Treatment of hepatitis C virus infection among people who are actively injecting drugs: a systematic review and meta-analysis. Clin. Infect. Dis. 57 (Suppl. 2), S80-S89 (2013).

190. Martinello, M., Hajarizadeh, B., Grebely, J., Dore, G. J. \& Matthews, G. V. HCV cure and reinfection among people with HIV/HCV coinfection and people who inject drugs. Curr. HIV/AIDS Rep. 14, 110-121 (2017).

191. Young, J. et al. Risk factors for hepatitis $C$ virus reinfection after sustained virologic response in patients coinfected with HIV. Clin. Infect. Dis. 64 1154-1162 (2017).

192. Midgard, $\mathrm{H}$. et al. Hepatitis $\mathrm{C}$ reinfection after sustained virological response. J. Hepatol. 64, 1020-1026 (2016).

193. Pineda, J. A. et al. Hepatitis C virus reinfection after sustained virological response in HIV-infected patients with chronic hepatitis C. J. Infect. 71, 571-577 (2015).

194. Alavi, M. et al. Injecting risk behaviours following treatment for hepatitis $\mathrm{C}$ virus infection among people who inject drugs: the Australian Trial in Acute Hepatitis C. Int. J. Drug Policy 26, 976-983 (2015).

195. Midgard, $\mathrm{H}$. et al. Changes in risk behaviours during and following treatment for hepatitis $\mathrm{C}$ virus infection among people who inject drugs: the ACTIVATE study. Int. J. Drug Policy 47, 230-238 (2017).

196. Artenie, A. A. et al. Short-term injection drug use changes following hepatitis $\mathrm{C}$ virus ( $\mathrm{HCV}$ ) assessment and treatment among persons who inject drugs with acute HCV infection. Int. J. Drug Policy 47, 239-243 (2017).

197. Dukers, N. H. et al. Sexual risk behaviour relates to the virological and immunological improvements during highly active antiretroviral therapy in HIV-1 infection. AIDS 15, 369-378 (2001).

198. Sacks-Davis, R., McBryde, E., Grebely, J., Hellard, M. $\&$ Vickerman, P. Many hepatitis $C$ reinfections that spontaneously clear may be undetected: Markov-chain Monte Carlo analysis of observational study data. J. R. Soc. Interface 12, 20141197 (2015).

199. Salazar-Vizcaya, L. et al. Hepatitis C virus transmission among HIV-infected men who have sex with men: modeling the effect of behavioral and treatment interventions. Hepatology 64, 1856-1869 (2016).

200. Coffin, P. O., Rowe, C. \& Santos, G. M. Novel interventions to prevent HIV and HCV among persons who inject drugs. Curr. HIV/AIDS Rep. 12, 145-163 (2015).

201. Hellard, M. et al. The impact of injecting networks on hepatitis $\mathrm{C}$ transmission and treatment in people who inject drugs. Hepatology 60, 1861-1870 (2014).

202. Vickerman, P. et al. The more you look, the more you find: effects of hepatitis $C$ virus testing interval on reinfection incidence and clearance and implications for future vaccine study design. J. Infect. Dis. 205 , 1342-1350 (2012). 
203. Hickman, M., De Angelis, D., Vickerman, P. Hutchinson, S. \& Martin, N. K. Hepatitis C virus treatment as prevention in people who inject drugs: testing the evidence. Curr. Opin. Infect. Dis. 28 576-582 (2015)

204. Martin, N. K., Hickman, M., Hutchinson, S. J., Goldberg, D. J. \& Vickerman, P. Combination interventions to prevent HCV transmission among people who inject drugs: modeling the impact of antiviral treatment, needle and syringe programs, and opiate substitution therapy. Clin. Infect. Dis. $\mathbf{5 7}$ (Suppl. 2), S39-S45 (2013).

205. Martin, N. K. et al. HCV treatment rates and sustained viral response among people who inject drugs in seven UK sites: real world results and modelling of treatment impact. J. Viral Hepat. 22, 399-408 (2015).

206. Scott, N. et al. Eliminating hepatitis $C$ virus as a public health threat among HIV-positive men who have sex with men: a multi-modelling approach to understand differences in sexual risk behaviour. J. Int. AIDS Soc. 21, e25059 (2018)

207. Zahnd, C. et al. Modelling the impact of deferring HCV treatment on liver-related complications in HIV coinfected men who have sex with men. J. Hepatol. 65, 26-32 (2016).

208. Scott, N., McBryde, E. S., Thompson, A., Doyle, J. S. \& Hellard, M. E. Treatment scale-up to achieve global $\mathrm{HCV}$ incidence and mortality elimination targets: a cost-effectiveness model. Gut 66, 1507-1515 (2017).

209. Boerekamps, A. et al. Declining HCV incidence in Dutch HIV positive men who have sex with men after unrestricted access to HCV therapy. Clin. Infect. Dis. https://doi.org/10.1093/cid/cix1007 (2017).

210. Pradat, P. et al. Incidence of new hepatitis C virus infection is still increasing in French MSM living with HIV. AIDS https://doi.org/10.1097 gad 0000000000001789 (2018).

211. Stockman, L. J. et al. Rapid hepatitis C testing among persons at increased risk for infection - Wisconsin, 2012-2013. Morb. Mortal. Wkly. Rep. 63, 309-311 (2014).

212. Kim, A. Y. et al. A simple strategy to identify acute hepatitis $C$ virus infection among newly incarcerated injection drug users. Hepatology 57, 944-952 (2013).

213. Cresswell, F. V. et al. Hepatitis C core antigen testing: a reliable, quick, and potentially cost-effective alternative to hepatitis $\mathrm{C}$ polymerase chain reaction in diagnosing acute hepatitis C virus infection. Clin. Infect. Dis. 60 263-266 (2015).

214. Martin, N. K. et al. Cost-effectiveness of HCV case-finding for people who inject drugs via dried blood spot testing in specialist addiction services and prisons. BMJ Open 3, e003153 (2013).

215. Hickman, M. et al. Increasing the uptake of hepatitis $C$ virus testing among injecting drug users in specialist drug treatment and prison settings by using dried blood spots for diagnostic testing: a cluster randomized controlled trial. J. Viral Hepat. 15 , 250-254 (2008).
216. Hayes, B. et al. Preference, acceptability and implications of the rapid hepatitis $\mathrm{C}$ screening test among high-risk young people who inject drugs. BMC Public Health 14, 645 (2014)

217. Barua, S. et al. Restrictions for Medicaid reimbursement of sofosbuvir for the treatment of hepatitis $C$ virus infection in the United States. Ann. Intern. Med. 163, 215-223 (2015).

218. Wang, C. C. et al. Acute hepatitis $C$ in a contemporary US cohort: modes of acquisition and factors influencing viral clearance. J. Infect. Dis. 196, 1474-1482 (2007).

219. van den Berg, C. H. B. S. et al. Female sex and IL28b, synergism for spontaneous viral clearance in hepatitis $c$ virus (HCV) seroconverters from a community-based cohort. PLOS ONE 6, e27555 (2011).

220. Zhang, M. et al. Correlates of spontaneous clearance of hepatitis $\mathrm{C}$ virus among people with hemophilia. Blood 107, 892-897 (2006).

221. Thomas, D. L. et al. The natural history of Hepatitis C virus infection: host, viral, and environmental factors. J. Am. Med. Assoc. 284, 450-456 (2000).

222. Tillmann, H. L. et al. A polymorphism near IL28B is associated with spontaneous clearance of acute hepatitis C virus and jaundice. Gastroenterology 139 , 1586-1592 (2010).

223. Thomas, D. L. et al. Genetic variation in IL28B and spontaneous clearance of hepatitis $\mathrm{C}$ virus. Nature 461, 798-801 (2009).

224. Grebely, J. et al. Potential role for interleukin-28B genotype in treatment decision-making in recent hepatitis C virus infection. Hepatology 52, 1216-1224 (2010)

225. Harris, H. E. et al. Does the clinical outcome of hepatitis $C$ infection vary with the infecting hepatitis $C$ virus type? J. Viral Hepat. 14, 213-220 (2007).

226. Liu, L., Fisher, B. E., Thomas, D. L., Cox, A. L. \& Ray, S. C. Spontaneous clearance of primary acute hepatitis $C$ virus infection correlated with high initial viral RNA level and rapid HVR 1 evolution. Hepatology 55 1684-1691 (2012)

227. Hajarizadeh, B. et al. Patterns of hepatitis $C$ virus RNA levels during acute infection: the $\ln ^{3}$ Study. PLOS ONE 10, e0122232 (2015).

228. Bruggmann, P. \& Litwin, A. H. Models of care for the management of hepatitis $C$ virus among people who inject drugs: one size does not fit all. Clin. Infect. Dis. 57 (Suppl. 2), S56-S61 (2013).

229. Bruneau, J. et al. Sustained drug use changes after hepatitis $C$ screening and counseling among recently infected persons who inject drugs: a longitudinal study. Clin. Infect. Dis. 58, 755-761 (2014).

230. Roux, P. et al. Innovative community-based educational face-to-face intervention to reduce HIV, hepatitis $C$ virus and other blood-borne infectious risks in difficult-to-reach people who inject drugs: results from the ANRS-AERLI intervention study. Addiction 111, 94-106 (2016).

231. El Sayed, A. et al. Sofosbuvir in the treatment of early HCV infection in HIV-infected men. HIV Clin. Trials $\mathbf{1 8}$, 60-66 (2017).
232. Vanhommerig J. W. et al Hepatitis C virus (HCV) antibody dynamics following acute $\mathrm{HCV}$ infection and reinfection among HIV-infected men who have sex with men. Clin. Infect. Dis. 59, 1678-1685 (2014).

\section{Acknowledgements}

The Kirby Institute is funded by the Australian Government Department of Health and Ageing. The views expressed in this publication do not necessarily represent the position of the Australian Government. The content is solely the responsibility of the authors. B.H., J.G., G.J.D. and G.V.M. are supported through the Australian National Health and Medical Research Council Fellowships (Early Career Fellowship (B.H.), Career Development Fellowships (J.G. and G.V.M.) and Practitioner Fellowship (G.J.D.)).

\section{Author contributions}

All authors contributed equally to the Review.

\section{Competing interests}

M.M. has received speaker payments from AbbVie. J.G. is a consultant and/or adviser and has received research grants from AbbVie, Bristol-Myers Squibb, Gilead and Merck. G.J.D. is an advisory board member and has received honoraria from AbbVie, Bristol-Myers Squibb, Gilead, Janssen, Merck and Roche, has received research grant funding from AbbVie, Boehringer Ingelheim, Bristol-Myers Squibb, Gilead, Janssen, Merck, Roche and Vertex and has received travel sponsorship from Bristol-Myers Squibb, Gilead, Janssen, Merck and Roche. G.V.M. has received research funding, advisory board payments and speaker payments from Gilead and research funding and speaker payments from Janssen. B.H. declares no competing interests.

\section{Publisher's note}

Springer Nature remains neutral with regard to jurisdictional claims in published maps and institutional affiliations.

\section{Review criteria}

Data for this Review were identified by searches of PubMed and Google Scholar up to 24 October 2017 using the terms "acute hepatitis C" "acute HCV", "recent hepatitis C" "recent HCV", "early hepatitis C" and "early HCV" in combination with the roots "epidemi*", "diagnos*” "natural history", "spontaneous clear*", "HIV", "men-who-have-sex-with-men", "men who have sex with men", "MSM", "inject drug*", "injecting drug*", "drug inject*", "drug use*", "PWID", "treat*" "direct acting antiviral*", "direct-acting antiviral*", "DAA", "interferon free", "interferon-free", "IFN free" and "IFNfree". No language or date restrictions were specified. The references of identified articles were manually searched for further relevant papers. Key abstracts at international meetings were also considered. ClinicalTrials.gov was searched for studies in progress.

\section{Supplementary information}

Supplementary information is available for this paper at https://doi.org/10.1038/s41575-018-0026-5. 